MARIA TERESA CUAMATZI PEÑA

\title{
HISTERECTOMIA DECORRENTE DE COMPLICAÇÕES DO PARTO EM UM GRUPO DE MULHERES MEXICANAS: UMA VISÃO SOCIOCULTURAL
}

Tese apresentada à Escola de Enfermagem de Ribeirão Preto da Universidade de São Paulo, para obtenção do Titulo de Doutor pelo Programa de pós-graduação, nível Doutorado em Enfermagem em Saúde Pública, inserido na linha de pesquisa Assistência à Saúde da Mulher no Ciclo Vital. 


\title{
UNIVERSIDADE DE SÃO PAULO \\ ESCOLA DE ENFERMAGEM DE RIBEIRÃO PRETO
}

\section{HISTERECTOMIA DECORRENTE DE COMPLICAÇÕES DO PARTO EM UM GRUPO DE MULHERES MEXICANAS: UMA VISÃO SOCIOCULTURAL}

\begin{abstract}
MARIA TERESA CUAMATZI PEÑA
Tese apresentada à Escola de Enfermagem de Ribeirão Preto da Universidade de São Paulo, para obtenção do Titulo de Doutor pelo Programa de pós-graduação, nível Doutorado em Enfermagem em Saúde Publica, inserido na linha de pesquisa Assistência à Saúde da Mulher no Ciclo Vital.
\end{abstract}

Orientadora: Profa. Dra. Marli Villela Mamede 


\section{UNIVERSIDADE DE SÃO PAULO \\ ESCOLA DE ENFERMAGEM DE RIBEIRÃO PRETO}

HISTERECTOMIA DECORRENTE DE COMPLICAÇÕES DO PARTO EM UM GRUPO DE MULHERES MEXICANAS: UMA VISÃO SOCIOCULTURAL

MARIA TERESA CUAMATZI PEÑA 


\section{MARIA TERESA CUAMATZI PEÑA}

Tese apresentada à Escola de Enfermagem de Ribeirão Preto da Universidade de São Paulo, para obtenção do Titulo de Doutor pelo Programa de pós-graduação, nível Doutorado em Enfermagem em Saúde Publica, inserido na linha de pesquisa Assistência à Saúde da Mulher no Ciclo Vital.

Aprovado em:

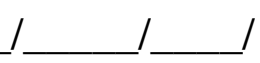

BANCA EXAMINADORA

Profa. Dra. Marli Villela Mamede

Instituição: Universidade de São Paulo - Escola de Enfermagem de Ribeirão Preto Assinatura

Profa. Dra. Flávia Azevedo Gomes

Instituição: Universidade de São Paulo - Escola de Enfermagem de Ribeirão Preto Assinatura

Profa. Dra. Marislei Sanches Panobianco

Instituição: Universidade de São Paulo - Escola de Enfermagem de Ribeirão Preto Assinatura

Profa. Dra. Raquel Gabrielli Biffi

Instituição: Centro Universitário Barão de Mauá do Curso de Enfermagem Assinatura

Profa. Dra. Maria Inês Brandão Bocardi

Instituição: Curso de Enfermagem da Universidade de Marília- UNIMAR Assinatura 
Autorizo a reprodução e divulgação total ou parcial deste trabalho, por qualquer meio convencional ou eletrônico, para fins de estudo e pesquisa, desde que citada a fonte.

\section{Ficha Catalográfica}

Preparada pela Biblioteca Central do Campus Administrativo de Ribeirão Preto IUSP.

Cuamatzi Peña, Maria Teresa

Histerectomia decorrente de complicações do parto em um grupo de mulheres mexicanas: uma visão sociocultural, 2004.

114 p. $29,7 \mathrm{~cm}$.

Tese de Doutorado- apresentada à Escola de Enfermagem de Ribeirão Preto/USP - Área de concentração: Saúde Pública.

Orientadora: Profa. Dra . Marli Villela. Mamede

1. Histerectomia. 2.qualidade de vida.

3.Interacionismo Simbólico. 4. complicação do parto 


\section{Dedicatória}

A Félix y Ernestina (t), meus pais obrigado pelo amor que se tiveram e me trouxeram este mundo e me ensinaram o melhor caminho para adquirir conhecimentos sobre a vida e assim obter minhas metas, me apoiando sempre com seus conselhos, carinho e amor.

A Froylán, meu querido esposo amigo, companheiro, que compartilhou comigo todos os momentos de minha vida de alegria, felicidade e tristeza, que com seu grande amor e grande carinho sempre me impulsionou e motivou para seguir adiante.

A David, Dennis y Elizabeth, meus amados filhos, luzes de minha vida que em todo os momentos de meu desenvolvimento profissional estiveram pressente, obrigado por seu, compreensão, respeito e amor que sempre me tiveram, me dando forças para seguir neste andar

A Edith y Ana Bertha, minhas Irmãs que me incentivaram e apoiou em todo momento para alcançar meu crescimento profissional.

A Araceli meu amiga querida que em todos momentos de minha vida, bons e maus, esteve sempre presente, me apoiando com seus sábios conselhos para meu andar neste caminho

A Yolanda meu grande amiga e companheira que sempre me ajudo, com o idioma e com as atividades cotidianas, sugiriendo acertadamente em tudo momento, para a culminação deste trabalho.

A Beatriz y Concepción, minhas queridas Amigas por sua grande amizade, e confiança para a realização deste trabalho, me motivando sempre a continuar para terminar esta etapa profissional de minha vida. 


\section{Agradecimentos}

A Deus, por todos os dons e bênções que me deu nesta vida, me iluminando sempre como uma mas de suas filhas, para alcançar minhas metas.

A Profa. Dra. Marli Villela Mamede, mais que orientadora, amiga, pela atenção, apoio e paciência que teve para o desenvolvimento deste trabalho. Com competência respeito e carinho conduziu -me sempre nessa jornada, não medindo esforços para que ela fosse além de consistente, também agradável. Foi muito bom ter sido orientada por você

A Profa. Dra. Marislei Sanches Panobianco, por ser muito humana, companheira, atenta e acertada com suas sugestôs para acrescentar este trabalho obrigado

A Profa. Dra. Flavia Azevedo Gomes, que com seu entusiasmo contribuiu para enriquecer e aprofundar meu trabalho, obrigada.

Profs Drs Raquel Gabrielli Biffi e Maria Inês Brandão Bocardi por suas contribuições na preforma. seus olhares possibilito enriquecer este estudo

A Maria Antonieta e Lenita, por seu grande apoio humano, com profissionalismo, atentas em todo momento para conclusão de meu trabalho obrigado amigas brasileiras.

A Marisa, Ruth, e Clicia, minhas amigas companheiras de aulas, juntas compartilhamos muitas experiências no caminhar. Quando relembre de bons momentos, com certeza vocês estarão neles.

A Margarita e Pilar por sua amizade e carinho, que me receberam em sua casa $e$ se esforçaram por fazer me sentir como de sua família obrigado.

A minha querida Facultad de Estúdios Superiores Zaragoza por me dar a oportunidade de realizar estudos de Doutorado fora do pais.

A minha querida Escola de Enfermagem de Ribeirão Preto/USP pela hospitalidade e pelo conhecimento adquirido, e a todos os professores que colaboraram na minha formação. 


\section{RESUMO}

CUAMATZI, P.M.T. Histerectomia decorrente de complicações do parto em um grupo de mulheres mexicanas: uma visão sociocultural. 2004. 114 p. Tese Doutorado - Escola de Enfermagem de Ribeirão Preto da Universidade de São Paulo.

Estudo de abordagem qualitativa que fundamentou-se em referenciais socioculturais, tomados da antropologia e apoiou-se no Interacionismo Simbólico, com o objetivo de compreender se a histerectomia realizada em mulheres, como conseqüência de complicações no parto, interfere em suas vidas. Buscou ainda, conhecer o significado da perda do útero para essas mulheres e identificar indicadores de mudanças em suas vidas após a cirurgia. Foram entrevistadas dez mulheres, em idade reprodutiva, independente de sua paridade, atendidas no Hospital Geral Dr. Gustavo Baz Prada, no Município de Nezahualcoyotl, Estado do México, nos anos de 2002 e 2003, para resolução da gravidez, e que, por complicações durante o parto, foram submetidas à histerectomia. Os dados coletados das entrevistas foram submetidos à análise de conteúdo e foi utilizada a técnica de análise temática. Foi possível identificar unidades temáticas que convergiram para três temas: Percepção dos motivos da histerectomia; A perda como motivo de sofrimento e Mudanças no corpo físico e no corpo social. Percebeuse que, de maneira geral, não foram esclarecidos às mulheres, os motivos que as levaram à mutilação. Em seu imaginário, tais motivos estiveram relacionados a um quadro sintomatológico, apresentado simplesmente pelo corpo biológico, como: temperatura alta, infecção, sangramento vaginal, anemia, distócias, risco para desenvolver câncer, ou ainda, para salvar suas vidas. Na perspectiva das mulheres, a perda do útero gerou um grande sofrimento, que recaiu muito mais em seus corpos sociais, uma vez que os corpos biológicos se recuperaram de maneira satisfatória. O conhecimento das questões subjetivas e socioculturais que permeiam o universo simbólico das mulheres possibilitou a identificação de metáforas da histerectomia, que interferem sobremaneira na qualidade de suas vidas, seja estigmatizando-as por não mais produzirem filhos ou punindo-as moralmente, através do abandono marital, dissolução do casamento e isolamento social, o que as impede de levar uma vida social e afetiva que as satisfaça.

Palavras-chave: qualidade de vida, histerectomia, complicações do parto 


\begin{abstract}
CUAMATZI P. M. T. Hysterectomy due to complications among mexican women: a socio cultural meaning. 2004. 114 p. Tese (Doutorado) - Escola de Enfermagem de Ribeirão Preto da Universidade de São Paulo.
\end{abstract}

It's a qualitative study, which background used social and cultural references. The symbolic interactionism was also used in order to understand the hysterectomy proceeding and women's lives after problems on delivery process. The study investigated the womb loss meaning and indicators of modifications in life styles. Ten women, all in reproductive period, were interviewed. The parity was not important in selection process. All women, assisted in Hospital Geral Dr. Gustavo Baz Prada, Nezahualcoyotl City, on Mexico State during 2002 and 2003, had complication during delivery and had been submitted to hysterectomy proceeding. The Content Analyze was used to understand data, this process revealed three thematic themes: understand the meaning of hysterectomy. Suffering the loss and changes on physical and social body. Almost all were not informed about the reasons for hysterectomy. Although for them the hysterectomy was explained based on their health status and symptoms as: fever, infections, vaginal bleeding, anemia, distocias, cancer risk and to save their lives. Losing the womb for women affects more the social bodies than biological ones, because the biological recuperation was satisfactory. Knowing the symbolic universe of subjective and social women's issues make possible to identify hysterectomy contradictions in their lives' quality and to demonstrate a stigma of not being a reproductive women. A moral punishment was also observed, as: husband's neglect, wedding's end, social isolation. All these issues obstruct them of having a satisfactory social and affective live.

Key words: quality of life, hysterectomy, complications on delivery. 


\section{RESUMEN}

CUAMATZI P.M.T. Histerectomía derivada de complicaciones del parto en un grupo de mujeres mexicanas: una visión sociocultural. 2004.114 p. Tesis de Doctorado - Escuela de Enfermería de Ribeirão Preto de la Universidad de São Paulo.

Estudio de abordaje cualitativo que se fundamento en referenciales socioculturales tomados de la antropología y se apoyo en el Interaccionismo Simbólico, como el objetivo de comprender si la histerectomía realizada en mujeres, como consecuencia de complicaciones en el parto, interfiere en la calidad de sus vidas. Se busco conocer el significado de la perdida del útero para esas mujeres e identificar indicadores de cambios en sus vidas después de la cirugía. Fueron entrevistadas diez mujeres en edad reproductiva independiente de su paridad, atendidas en el Hospital General Dr. Gustavo Baz Prada, en el Município de Nezahualcoyotl, Estado de México, en los años 2002 e 2003, para atenderse del embarazo, y que por complicaciones durante el parto, fueron sometidas a la histerectomía. Los datos colectados de las entrevistas fueron sometidos al análisis de contenido y fue utilizada la técnica de análisis temático. Fue posible identificar unidades temáticas que convergieron en tres temas: Percepción de los motivos de la histerectomía; La perdida como motivo de sufrimiento y Cambios en el cuerpo físico y en el cuerpo social. Se percibió de manera general, que no fueron esclarecidas a las mujeres los motivos que las llevo a la mutilación. En su imaginario, tales motivos estuvieron relacionados a un cuadro sintomatólogico, presentando simplemente por el cuerpo biológico, como: temperatura alta, infección, sangrado vaginal, anemia, distocias, riesgo para desarrollar cáncer, o todavía para salvar sus vidas. En la perspectiva de las mujeres, la perdida del útero generó un gran sufrimiento, que recayó mucho mas en sus cuerpos sociales, una vez que los cuerpos biológicos se recuperaron de manera satisfactoria. El conocimiento de las cuestiones subjetivas y socioculturales que pernean el universo simbólico de las mujeres posibilitó la identificación de metáforas de la histerectomía, que interfieren de sobre manera en la calidad de sus vidas, estigmatizándolas por no producir mas hijos o colocándolas moralmente, a través del abandono marital, disolución del casamiento y aislamiento social, lo que les impide llevar una vida social y afectiva que las satisfaga.

Palabras clave: calidad de vida, histerectomía, complicaciones del parto. 


\section{LISTA DAS SIGLAS E ABREVIATURAS}

CEPAL Comissão Econômica para a América Latina e o Caribe

CIPD Conferência Internacional de População e desenvolvimento

ENSA Pesquisa Nacional de Saúde

E Entrevistada

EDO Estado

IMSS Instituto Mexicano do Seguro Social

ISSSTE Instituto de segurança e serviço social para os trabalhadores do

Estado

INEGI Instituto Nacional de Estadística

NVR Recém-nascidos Vivos.

OPS Organização Pan-americana da Saúde

OMS Organização Mundial da Saúde

PAPV Programa arranque parecido de vida

PEMEX Petróleos Mexicanos

PNS Programa Nacional Sáude

QV Qualidade de Vida

TLC Tratado de Livre Comércio

SSA Secretária de Saúde

SNSM Sistema Nacional de Saúde Mexicano

UNICEF Fundo das Nações Unidas para a Infância 


\section{SUMÁRIO}

RESUMO

ABSTRACT

RESUMÉN

INTRODUÇÃO

$\begin{array}{ll}\text { OBJETIVOS } & 10\end{array}$

CAPITULO I SOBRE O OBJETO DE INVESTIGAÇÃO

1. A dimensão sócio-cultural

\section{CAPITULO II REFERENCIAL TEÓRICO METODOLOGICO}

$\begin{array}{ll}2.1 \text { Abordagem Qualitativa } & 18\end{array}$

$\begin{array}{ll}2.2 \text { Quqlidade de vida } & 19\end{array}$

2.3 O Interaccionismo Simbólico 26

CAPITULO III DESENHO METODOLOGICO

3.1 Contexto de Pesquisa 32

$\begin{array}{ll}3.2 \text { Sujeitos do Estudo } & 40\end{array}$

3.3 Coleta os dados 42

3.4 Tratamento e Analise dos dados 44

\section{CAPITULO IV RESULTADOS E DISCUSSÇÃO}

4.1 Caracterizando das mulheres estudadas 49

4.2 Descrição pessoal das mulheres entrevistadas 51

4.3 A Histerectomia por complicação do parto na vida das mulheres estudadas

.4.3.1 Percepção dos motivos da histerectomia 68

4.3.2 Aperda como motivo de Sofrimento 74 
4.3.2.1 A experiência de um corpo vazio: o caos

4.3.2.2 Percebendo-se inferiorizada

4.3.2.3 Conviviendo com desajuste social e conjugal

4.3.2.4 Tendo um futuro incerto

4.3.3 Mudanças no corpo físico e no corpo social

4.4 A síntese: Metáfora da Histerectomia e

repercussões na qualidade de vida

CAPITULO V .-CONSIDERAÇÓES FINAIS

CAPITULO VI REFERÊNCIAS BIBLIOGRAFICAS

\section{ANEXO}

APÊNDICES 


\section{INTRODUÇÃO}

Grandes avanços em matéria de morbi-mortalidade materna são observados, em nível mundial, entretanto existem sérios problemas e atrasos, principalmente em países em desenvolvimento, cujos sistemas de saúde, em geral, não têm a infraestrutura adequada e a cobertura de atenção é deficiente. Em muitos destes países, não se conta com material de insumos equipe e medicamentos necessários para a atenção ao parto e às suas complicações, como também a condição de vida de grande parte da população caracteriza-se pela extrema pobreza (ROMO, 2002).

Segundo Romo (2002), tem havido esforços na região latino-americana e caribenha para a diminuição de morbi-mortalidade materna através do desenvolvimento de ações específicas à atenção de saúde à mulher, o que tem representado, em certa medida, diminuição deste indicador na região. No entanto, há contrates na região quando se observam, de um lado, países como Cuba e Costa Rica, representando uma grande diferença na diminuição da morbi-mortalidade materna, e de outro lado, os demais países, incluindo o México.

Nos países em desenvolvimento, de uma forma geral, há grandes dificuldades de acesso da população aos serviços de saúde, baixa cobertura de atenção à saúde e uma questionável qualidade da atenção, o que coloca as mulheres em maior risco de desenvolver problemas de morbi-mortalidade materna. Os problemas mais comuns relacionam-se a complicações do parto e puerpério como: ruptura uterina, 
atonia uterina, hemorragia, pré-eclâmpsia, eclâmpsia e Síndrome de Help (ROMO, 2002).

Tais complicações multiplicam-se nos países em desenvolvimento, onde quase metade dos partos ocorre sem a ajuda de uma pessoa qualificada na atenção ao parto, e quanto ao pós-parto, estima-se que somente $5 \%$ das mulheres recebem a atenção necessária.

Segundo a OMS (2002), mais de uma mulher morre a cada minuto no mundo, devido a complicações durante a gravidez, parto e puerpério. São 585.000 mulheres que morrem a cada ano, e isso demonstra a necessidade da existência de recursos e serviços disponíveis, sobretudo nos países em desenvolvimento, para que isso pudesse ser evitado.

Afirma Acosta (2000), que nos países pobres, as principais complicações e os maiores riscos de morrer, enfrentados pelas mulheres no período reprodutivo, acontecem durante e após o parto, ao darem à luz sob a assistência de pessoal não qualificado.

Romo (2002) esclarece que a situação atual no mundo, com especial ênfase no contexto latino-americano e, concretamente no México, fez com os governos estabelecessem uma série de objetivos e prioridades nas políticas de população e saúde, conforme descritos e expostos no Programa Nacional de Saúde Reprodutiva 2001-2006 do México.

A morbi-mortalidade materna no México representa um problema multifatorial de saúde pública, pois suas causas são evitáveis, o que evidencia sinais de grande injustiça social. Isso também é observado nos países de menor desenvolvimento econômico, onde se encontram as taxas mais altas de mortes maternas, ou seja, 
locais onde as mulheres pobres são as que têm maior risco de morrer por problemas de gravidez, parto ou puerpério.

Cabe ressaltar os contrastes entre os países da Europa e América do Norte com a maioria dos países pertencentes aos continentes africano e asiático, além da região latino-americana e do México, que não se afasta muito desta dinâmica. No México existem indicadores que refletem que os resultados das políticas de saúde em algumas regiões do país se contrastam com os de outras.

Durante a ultima década, a taxa de mortalidade materna do México mostrou uma tendência ligeiramente decrescente em 1990, registrando 5,4 falecimentos maternos por 10.000 nascidos vivos registrados (NVR), enquanto que no ano 2000 este indicador alcançou o valor de 4,68 (SNS, 2001).

As principais causas de morte materna no México são, hemorragia da gravidez e do parto $57,2 \%$, toxemia da gravidez $25 \%$, complicações do puerperio $8,2 \%$, parto obstruído $1,9 \%$, aborto $7,0 \%$, outras causas obstétricas indiretas $0,7 \%$. Presume-se que exista um importante sub-registro da mortalidade materna em nosso país, sobretudo nas áreas rurais e comunidades indígenas. Das 1.310 mortes maternas registradas no ano de $2000,67,3 \%$ ocorreram em 10 estados do centro e sudeste: Estado do México, Veracruz, Distrito Federal, Guerrero, Puebla, Oaxaca, Chiapas, Jalisco, Guanajuato e Michoacán (PAPV, 2001).

Da mesma forma, identifica-se pelo menos 391 municípios que apresentaram pouco mais de $70 \%$ das mortes maternas registradas nos últimos três anos. A acessibilidade aos serviços de saúde é uma das principais causas que influem na mortalidade materna.

No ano $2000,17 \%$ das mortes maternas ocorreram no lar e pouco mais de $65 \%$ em hospitais públicos, sendo que a grande maioria dessas mulheres não 
tinham seguro social. Tal fato assinala a necessidade de se estabelecer uma coordenação com todas as instituições do Sistema Nacional de Saúde, assim como de desenhar estratégias especificas para dar resposta a esta problemática da mortalidade, em cada estado.

A Secretária de Saúde do Programa Nacional de Saúde (2001-2006) estabelece que a mortalidade materna é um problema de saúde pública e, define-a como um indicador setorial estratégico de desempenho e resultado. Considera que a saúde materna constitui um dos cinco problemas de alta prioridade para o setor saúde, entretanto, a mesma Secretaria se contradiz ao não incluir o indicador da mortalidade materna entre os seus 65 indicadores de apoio à saúde da população.

Este fato se mostra alarmante, porque reflete que o setor saúde não está considerando a morte materna como um problema prioritário. Do total das mulheres que morreram no México no ano de 2000 por complicações durante a gravidez, parto ou puerpério, $65 \%$ não estavam asseguradas, ou seja, classificadas como população aberta, atendidas nos hospitais públicos (PAPV, 2001).

No México, a participação do setor público na atenção ao parto é muito importante, apesar de ser ainda insuficiente. Segundo dados da Pesquisa Nacional das instituições deste setor, $10 \%$ dos partos ainda são atendidos na casa da mulher ou da parteira tradicional; $67.7 \%$ em alguma das instituições do setor saúde. Estimase que há uma média de 2.5 milhões de mulheres grávidas por ano, das quais ao redor de 370 mil são atendidas por pessoal não qualificado (ENSA, 2000).

A informação sobre a participação dos setores público e privado na atenção ao parto, por entidade federativa do país, indica que em Baja California Sur, Distrito Federal, Aguascalientes, Coahuila, Jalisco, Baja California, Nuevo León, Sonora e Sinaloa estão os níveis de atenção mais altos, com cobertura muito próxima de 
100\%. No entanto, em Guerrero, Tabasco, Tlaxcala, Oaxaca e Chiapas prevalecem porcentagens muito altas de partos que não são atendidos, nem em instituições públicas, nem em privadas. Em Oaxaca e Chiapas mais de $40 \%$ dos partos são atendidos no lar.

Os problemas relacionados com a gravidez, parto e puerpério, no país, representam a quarta causa de morbi-mortalidade de mulheres em idade reprodutiva, e estes estão altamente determinados pelas condições socioeconômicas, pela alta incidência de gravidez precoce, abortos freqüentes e mal atendidos. Nos casos em que ocorrem complicações, muitos são levados à histerectomia (CENSO, 2000).

Em nossa experiência profissional na área da saúde reprodutiva, vimos observando, no México, que as mulheres que apresentaram riscos durante a gravidez, os quais não puderam ser atenuados ou modificados, estes convertem-se em risco materno, desencadeiam danos durante o processo de trabalho de parto e parto, muitas vezes levando à morte, sobretudo por atonia uterina, resultando em choque hipovolêmico. Vimos observando ainda, um grande número de casos de mulheres que apresentam complicações durante o trabalho de parto e parto, mas que se livraram de morrer a custa de intervenções como a histerectomia.

Bakshi e Meyer (2000), afirmam que a incidência de histerectomia em emergências obstétricas no parto é de 0,4 a 1,3 por cada 1000 mulheres, na União Americana e Canadá. As indicações mais freqüentes de histerectomia por causas obstétricas estão relacionadas à hemorragia presente na incisão da cesárea, especialmente naqueles casos de complicação devida à placenta acreta e hemorragia pós-parto, secundária à atonia uterina. 
Em 1994, a estatística da Secretaria de Saúde no México possibilita pensar que o aumento da taxa de cesáreas nas últimas duas décadas contribuiu para um aumento na incidência de placenta acreta, portanto foi a mais comum indicação para a extirpação do útero durante a cesárea. Sabe-se que a histerectomia é necessária em casos de câncer uterino, menstruação excessiva, recorrente e que cause anemia, ou em casos de prolapso do útero, e outras complicações como as de parto.

Em estudo realizado no Hospital da Mulher da Secretaria de Saúde no México, de um total de 276 casos de cesáreas, observou-se uma alta freqüência de histerectomia de emergência (201 casos), 72,87\% cujas indicações mais comuns foram relacionadas às seguintes causas: inserção anormal de placenta (135 casos), correspondendo a 48,91\%, e atonia uterina, que não respondem ao tratamento médico e chegam a romper o útero (66 casos - 23,91\%) (Secretaria de Saúde de México, 2001).

No ano de 2000 foram realizadas 57.800 histerectomias nos hospitais públicos do México; $60 \%$ delas em mulheres entre 35 e 45 anos, com miomatose uterina, câncer cérvico-uterino em estágios I, II, e III e as $40 \%$ restantes foram em mulheres entre 15 e 34 anos de idade, com complicação de aborto séptico, hemorragia pela atonia uterina no trabalho de parto e parto e infecção puerperal, causas indiretas e diretas (SSA, 2000).

Mondragón (2000) menciona a sepsis abdominal pós-cesárea como indicação para realização de histerectomia e ressalta o papel da cicatriz uterina, decorrente da cesárea, no aumento de risco à histerectomia, durante a condução do parto (40\%). A autora chama a atenção sobre a possibilidade de ocorrer implantação profunda da placenta, ruptura uterina ou placenta prévia quando uma mulher apresenta história de cesárea anterior. 
Vários estudos sobre a morbimortalidade materna no mundo, especialmente nos países em desenvolvimento como México e toda Latinoamerica identificam que a principal complicação durante o parto e puerpério é a hemorragia, em conseqüência da atonia uterina, ou ruptura uterina como complicação de uma cesárea realizada de forma inadequada (MONDRAGÓN, 2000).

Segundo Dildy e Scott (2000), a dequitação na cesárea é o fator de risco mais freqüente, provavelmente por incrementar a possibilidade de placenta anormal. O manejo atual das complicações, como a atonia uterina, melhorou sensivelmente devido à introdução do uso de prostaglandinas, aos avanços no suporte anestésico e hematológico, além da redução do uso de fórceps, diminuindo assim o trauma uterino.

No entanto, o incremento de incisões uterinas em cesáreas prévias tem trazido seqüelas para gestações posteriores (BAKSHI ; MEYER, 2000). As cesáreas prévias favorecem a implantação da placenta anormal, que pode ser identificada usando ecografia de alta resolução, particularmente com transdutor transvaginal ou Doppler, ou a Ressonância Nuclear Magnética (RNM).

As mulheres que apresentam história prévia de incisão uterina por cesárea incrementam em 27 vezes a probabilidade de adquirir histerectomias por causas obstétricas, quando comparadas com aquelas que não apresentam esse antecedente.

Para evitar esta grave complicação que põe em risco a vida da mãe, é necessário um bom controle pré-natal (BAKSHI; MEYER , 2000).

A identificação prévia das pacientes de alto risco ao parto ajuda a realizar um procedimento programado, evitando com isso complicações inesperadas, podendo 
em alguns casos evitar ou demorar a decisão de realizar a histerectomia (WONG, 1999).

Apesar do valor da histerectomia para salvar vidas, especialmente em situações de emergências obstétricas, esta poderá trazer sérios problemas sociais, afetivos e psicológicos para a vida das mulheres.

Numerosos estudos destacam os efeitos negativos da histerectomia na vida da mulher, ocasionando depressão, ansiedade, diminuição da auto-estima, e alteração na função sexual (LANGER, 1995).

Para Freeman (1993), a histerectomia se relaciona com problemas emocionais específicos, a equipe de saúde somente dirigir as situações anatômicas, fisiológicas e psicológicas que justificam a extirpação do útero, mas, em geral se detêm poucos a considerar seu valor inconsciente ou simbólico. Pela mulher o valor simbólico do útero, é de grande importância e deve ser dirigido de certa forma por ela antes de considerar tal indicação. Também assinala que a maioria das mulheres expressa sentimentos ambivalentes ante a perda desta parte valiosa de seu corpo, a perda do útero freqüentemente aguarda sentimentos, ambivalentes conscientes ou inconscientes, vinculados com seu valor simbólico.

Observa-se que a perda do útero afeta as esferas psicológica e social da mulher, e de um modo geral, os profissionais de saúde não atentam para tais aspectos. Portanto, a histerectomia realizada na idade reprodutiva parece ser uma situação de difícil aceitação por parte das mulheres e associado a isto, os profissionais de saúde não as preparam para a situação a ser enfrentada posteriormente a este processo, especialmente nos assuntos relacionados à sua vida familiar e conjugal. 
Preocupadas com esta dimensão da vida das mulheres que se submeteram à histerectomia, fazemos o seguinte questionamento: Qual é a situação das mulheres que se submeteram à histerectomia em decorrệncia de complicações no parto? A histerectomia interfere na qualidade de suas vidas? As respostas a estas questões tornaram-se o foco de nosso trabalho. Não somente pela carência de literatura que focalize a atenção na dimensão sociocultural das relações entre histerectomia por complicação de parto e qualidade de vida, mas especialmente pelas questões simbólicas que rodeiam o problema.

Acreditamos que a analise das experiências vividas pelas mulheres que foram submetidas à histerectomia por complicações durante o parto possa ampliar o olhar dos profissionais de saúde sobre sua prática, e oferecer uma melhor orientação à mulher e ao casal, sobre sua situação emocional, física e social, para elevar qualidade sua de vida. 


\section{OBJETIVOS}

- Compreender se a histerectomia realizada em mulheres, em decorrência de complicações no trabalho de parto e parto, interfere na qualidade de suas vidas.

\section{ESPECÍ́FICOS}

- Conhecer o significado da perda do útero para as mulheres que se submeteram à histerectomia em decorrência de complicações no trabalho de parto e parto.

- Identificar indicadores de mudanças que interferem na qualidade de vida das mulheres depois de serem submetidas à histerectomia por complicações de trabalho de parto e parto. 


\section{CAPITULO I: Sobre o objeto de investigação}

\section{A dimensão sociocultural}

Para que possamos ampliar a nossa visão sobre o objeto de investigação, torna-se de fundamental importância tecer considerações sobre aspectos antropológicos do processo saúde-doença.

Para entender a relação que as pessoas fazem entre a forma como elas vivem os seus cotidianos e seu estado de saúde faz-se necessário compreender como a cultura exerce influência na determinação do estado de saúde-doença das pessoas.

O conceito de cultura, na perspectiva antropológica, auxilia-nos nessa direção, pois denota um padrão de significados transmitidos historicamente, incorporado por símbolos, por um sistema de concepções herdadas, expressos em formas simbólicas, por meio das quais os homens comunicam, perpetuam e desenvolvem seu conhecimento e suas atividades em relação à vida (GEERTZ,1989).

A cultura é, portanto, tratada de modo mais efetivo como um sistema simbólico, por meio do isolamento de seus elementos para especificar as relações internas entre tais elementos, e também para caracterizar todo o sistema, de acordo 
com os símbolos básicos em que a cultura é organizada, com as estruturas subordinadas e com os princípios ideológicos nos quais está baseada (GEERTZ,1989).

O ser humano precisa, portanto, de fontes simbólicas de iluminação para encontrar apoio no mundo, pois, como explica Geertz (1989), a qualidade nãosimbólica, constitucionalmente gravada em seu corpo, lança uma luz muito difusa. Assim, o seu comportamento seria virtualmente ingovernável, um caos de atos sem sentido e de explosões emocionais e sua experiência não teria praticamente qualquer forma. Fica evidente que é no locus da cultura, que são articuladas as concessões, os conflitos, tradições e mudanças. É no espaço cultural que surgem os sentidos, os significados, inclusive os problemas relacionados à saúde.

Para o entendimento dos problemas de saúde, a perspectiva médica - de acordo como o modelo explicativo de enfermidades (disease) - é orientada principalmente para a descoberta e a quantificação das informações psicoquímicas sobre o paciente, e não para fatores menos mensuráveis, como os sociais e emocionais. Segundo Helman (1994) a medicina moderna valoriza mais as dimensões físicas da doença, não incluindo as dimensões sociais e psicológicas dos problemas de saúde, nem o contexto em que os mesmos aparecem, e muito menos o que determina o significado da enfermidade (disease) para o paciente e para aqueles que o rodeiam.

Ainda segundo Helman (1994), a doença (illness) - de acordo com o modelo explicativo do paciente - é a resposta subjetiva do paciente, e de todos os que cercam seu mal-estar. Particularmente, é a maneira como a origem e a importância do evento são interpretados, o efeito deste sobre seu comportamento e relacionamento com outras pessoas, e as diversas providências tomadas por ele 
para remediar a situação. Portanto, a definição de doença não inclui somente a experiência pessoal do problema de saúde, mas também o significado que o indivíduo confere à mesma.

Este modelo explicativo de doença, utilizado pelo paciente, parte de um modelo conceitual muito mais amplo do que o modelo médico, pois segundo Helman (1994), considera-se que tanto o significado conferido aos sintomas, quanto a resposta emocional aos mesmos, são influenciados pelo background do paciente e sua personalidade, bem como pelo contexto cultural, social e econômico em que aparecem. Helman (1994), destaca que a mesma enfermidade (disease) ou o mesmo sintoma podem ser interpretados de maneiras completamente diferentes por dois pacientes de culturas e contextos distintos. Estas diferenças irão influenciar os seus comportamentos subseqüentes e os tipos de tratamentos procurados por eles.

No que diz respeito ao nosso objeto de estudo, o interesse sobre a influência dos processos sociais e culturais na definição de enfermidades e doença não é tão recente.

Uma revisão histórica realizada por Dennerstein e Van Hall (1986), revela que desde o ano 2000 a.C., como indicado em papiro Kahan, os egípcios viam o útero como tendo um efeito poderoso e importante na saúde mental da mulher. Consideravam o útero como uma criatura independente, capaz de ter sua própria vontade e de caminhar dentro do corpo da mulher, causando vários sintomas mórbidos. Diversos tratamentos eram utilizados, para atrair o útero para seu lugar correto, no organismo da mulher. Outro aspecto histórico relacionado ao útero, identificado por estes autores, está relacionado com o conceito definido por Hipócrates e Platão de que a fertilização da mulher, promovendo a gravidez, era necessária para produzir na mulher a "gratificação uterina" e, conseqüentemente, a 
sua estabilidade emocional. Os autores destacam que Hipócrates prescrevia o casamento para as virgens ou viúvas que sofriam daquilo que chamavam de "sufocação do útero", e que Platão, em sua obra "Timeo", escreveu.que "o útero é um animal que anseia por gerar filhos, e quando fica estéril por muito tempo depois da puberdade, ou quando fica perturbado, leva a mulher à angústia extrema, sendo capaz de promover nela todas as espécies de enfermidades.

Para os autores acima referidos, este conceito parece ter sido a base da visão psicanalítica que apresenta a sexualidade feminina como sendo passiva, masoquista e dependente da capacidade de ter filhos. Identificaram ainda, certas características históricas da personalidade feminina que são consideradas importantes na adaptação da mulher ao seu útero. Relatam que Aretacus da Capadocia, um médico grego que viveu por volta de 200 anos d.C., sugeria que as mulheres jovens e aquelas facilmente irritáveis eram mais vulneráveis aos problemas relacionados ao útero. Os autores afirmam que esta noção parece ser válida até hoje, servindo de apoio para os estudos prospectivos, que investigam os efeitos do estado psicológicos anterior à cirurgia de útero sobre os resultados no pós-operatório.

No levantamento bibliográfico revisado, para compreender como os estudos com mulheres que são submetidas a histerectomia foram desenvolvidos, encontrouse que, ao final da década dos anos 1970 e 1980, a maioria dos trabalhos publicados destacava os efeitos negativos da cirurgia na mulher, causando depressão, ansiedade, diminuição na auto-estima e alteração na função sexual.

Bernhard (1986), em um estudo exploratório e longitudinal com 63 mulheres investigou a relação entre as expectativas que as mulheres tinham sobre o efeito da histerectomia em sua sexualidade e a experiência que realmente vivenciavam depois da mesma. A autora encontrou que a sexualidade, antes da histerectomia, 
não era a preocupação principal e que as mulheres estavam muito mais preocupadas com sua saúde em geral. A autora observou que muitas delas apresentaram um misto de expectativas e resultados positivos e negativos que não estavam claramente relacionadas com os resultados vivenciados.

Revisando a literatura em enfermagem, encontramos que um dos primeiros estudos com mulheres submetidas à histerectomia foi realizado por Williams (1976), onde a autora comparou a convalescença pós-cirúrgica de 32 mulheres angloamericanas e méxico-americanas. A investigação foi realizada 5 meses depois da cirurgia e teve como objetivos verificar se a etnia afetava a duração da convalescença, identificar os estresses provocados pela cirurgia e se estes eram vivenciados de maneira diferente pelos dois grupos de mulheres. A autora não encontrou diferença entre os dois grupos, visto que a convalescença foi avaliada como inadequada em ambos os grupos. Verificou-se ainda, que os padrões culturais referentes aos papéis masculino e feminino pareciam ser importantes na modulação das percepções das mulheres sobre os efeitos da cirurgia de histerectomia.

Reis, em 1987, ao estudar as necessidades psico-biológicas e psicossociais de um grupo de 50 mulheres histerectomizadas, no período de hospitalização pósoperatória, encontrou que as necessidades de locomoção, eliminação, sexualidade e cuidado corporal estavam afetadas, indicando alterações na imagem corporal, nas necessidades de segurança emocional, auto-realização e aceitação.

A histerectomia realizada no ciclo grávido-puerperal implica uma decisão rápida, angustiante e difícil, pois muitas vezes, trata-se de mulheres jovens, sadias que, devido a complicações inerentes a este período, constitui-se em única alternativa para evitar a morte. 
Caliri (1994), desenvolveu um estudo qualitativo com 8 mulheres submetidas à histerectomia em decorrência de leiomiomas, com o objetivo de compreender e descrever o processo vivenciado pelas participantes sob as suas próprias perspectivas. Para a autora os resultados permitiram compreender que as mulheres estudadas percebiam uma situação de ambigüidade que, por um lado identificavam a necessidade de submeterem-se à histerectomia para resolver os problemas que as impediam de usufruir uma vida normal e, por outro lado viviam a incerteza sobre as conseqüências da falta do útero. Segundo a autora, a situação de incerteza surgida pela tensão entre o "self" privado e a "identidade pública" da mulher que se submeteu à histerectomia, apresentava a elas uma visão de uma mulher "vazia, "fria" e "diferente" das outras, que as direcionava a ações e interações no sentido de resolver a sua situação. Caliri (1994) afirma que estas ações e interações caracterizam o processo central vivenciado por elas "tentando resolver as incertezas frente à histerectomia".

Garcia e Sobrado (2000), pesquisaram 85 pacientes menopáusicas atendidas em consulta externa, num hospital geral de Havana, Cuba. Deste grupo, foram selecionadas 12 mulheres com menopausa natural e 23 histerectomizadas, às quais foram aplicadas uma entrevista e 3 testes psicológicos, para registrar níveis da ansiedade situacional e pessoal, explorar conflitos e conhecer o desenvolvimento da auto-estima que apresentaram depois destes processos, tanto cirúrgicos como natural. Os sintomas encontrados com mais freqüência, em ambos os grupos foram: depressão, ansiedade, insônia, vergonha e irritabilidade.

A ansiedade foi mais notória no grupo das mulheres operadas, assim como a baixa auto-estima. Elas percebem que também existe uma deterioração da autoimagem, em termos de qualidades de personalidade, como, por exemplo, sentem-se 
indecisas, desconfiadas de suas possibilidades, dependentes, expressam sentimentos de perda não só em relação ao físico, mas também em relação ao emocional, o que se evidencia em algumas expressões como: "sou um desastre como pessoa, incapaz de enfrentar situações ou obstáculos"; "penso que não sirvo como mulher, porque perdi tudo na ordem sexual". Mas as mesmas mulheres sentem-se frustradas porque não tiveram a oportunidade de ser mãe, sofrem de maior depressão, a ponto de ficarem com problemas psiquiátricos, diferentemente daquelas que já tiveram filhos.

Garcia (2000) revela que os transtornos sexuais mais freqüentes após a histerectomia são a dispareunia e o desejo sexual diminuído, enquanto que os transtornos psiquiátricos surgidos depois da intervenção são a ansiedade e a depressão reativa, os quais são motivos mais freqüentes de consulta. Segundo este autor a histerectomia reaviva um duelo prévio não resolvido sobre a maternidade, convertendo-se assim, em um duelo patológico. 


\section{CAPITULO II: Referencial Teórico-Metodólogico}

\subsection{A abordagem Qualitativa}

O presente trabalho é um estudo de abordagem qualitativa, visto que o mesmo apóia-se no interesse por compreender a complexidade de um fenômeno que, decididamente, não se limita apenas a dados estatísticos. A escolha por esta abordagem pode ser caracterizada como uma tentativa de compreensão detalhada dos significados e das características situacionais apresentadas pelas entrevistadas, em lugar de produções quantitativas. Interessou-nos sobretudo, conhecer, na perspectiva das próprias mulheres, o significado da histerectomia em suas vidas, a qual foi realizada em decorrência de complicações do trabalho de parto e parto, bem como saber as repercussões sobre a qualidade de suas vidas.

Foram mantidos contatos diretos com as participantes do estudo, na tentativa de verificar as suas condições de vida e conhecer as experiências vivenciadas, de forma a possibilitar uma compreensão mais aprofundada do objeto sob investigação.

Por outro lado, vimos no interacionismo simbólico o referencial teórico metodológico que pudesse nos auxiliar na compreensão sobre o significado da perda do útero na vida de mulheres que se submeteram à histerectomia por ocasião de trabalho de parto e parto, por ser um referencial que trata do comportamento humano e da interação social. $\mathrm{O}$ mesmo favorece a compreensão sobre o 
significado que as pessoas dão às coisas no ambiente natural e como essas pessoas transformam esse significado por meio de um processo interpretativo.

\subsection{Qualidade de Vida}

A qualidade de vida tem sido preocupação constante do ser humano, desde o início de sua existência e, atualmente, constitui um compromisso pessoal na busca contínua por uma vida saudável. Ela pode ser entendida à luz de um bem-estar indissociável das condições do modo de viver, como saúde, moradia, educação, lazer, transporte, liberdade, trabalho, auto-estima, entre outras coisas importantes.

O termo qualidade de vida tem recebido uma grande variedade de definições ao longo dos anos, podendo ser baseado em três princípios fundamentais, que são a capacidade funcional, o nível socioeconômico e a satisfação (GONZALEZ, 1993). A qualidade de vida também está relacionada com os seguintes componentes: capacidade física, estado emocional, interação social, atividade intelectual, situação econômica e proteção à saúde.

Consiste na sensação de bem-estar que se pode experimentar pelas pessoas e que representa a soma de sensações subjetivas e pessoais do sentir-se bem. É um conceito multidimensional que inclui estilo de vida, moradia, satisfação na escola assim como no emprego e uma boa situação econômica. Por isso ela é conceitualizada através de um sistema de valores ou perspectivas que varia de uma pessoa para outra (GATH,1992).

Segundo Hallert (1999) qualidade de vida é o conjunto de características que definem o bem-estar e o funcionamento de uma pessoa, em um dado momento. A medição destas características deve abranger o âmbito físico, psicológico e social do 
indivíduo. Para Ungo (1999) a qualidade de vida é um processo dinâmico que requer uma constante adaptação, sobretudo quando se trata de medi-la em pacientes, cujas expectativas do dia a dia e, muitas vezes, de minuto a minuto, são distintas em sua dinâmica bio-psico-social.

Para Ferrans (1994) qualidade de vida é entendida como "o sentido de bemestar de uma pessoa, o qual provém da satisfação ou insatisfação com as áreas da vida que são importantes para ela". Esta definição parte da compreensão sobre os valores que as pessoas dão aos aspectos que têm impacto sobre a qualidade de suas vidas. Além disso, para a autora, o conceito de satisfação é usado como um constructo de qualidade de vida, pois permite comparar a avaliação sobre aquilo que é desejado com as condições de vida atual do indivíduo.

Segundo Schalock. (1996), na realidade, o conceito de qualidade de vida varia de acordo com a visão de cada individuo. Para alguns, ela é considerada como unidimensional, enquanto para outros, é conceituada como multidimensional.

Para Ferrans e Powers (1994), a qualidade da vida é um conceito importante e crítico no cuidado à saúde. O mesmo se desenvolveu predominantemente nas três décadas passadas. Afirmam que a sua clareza conceptual é extremamente importante, pois os resultados de investigações sobre as dimensões da qualidade de vida poderão ajudar na prática clínica e na atribuição de recursos de cuidado à saúde.

O interesse pela qualidade de vida existiu desde tempos imemoráveis, entretanto, a aparição do conceito como tal e a preocupação pela avaliação sistemática e científica do mesmo é relativamente recente. A idéia começa a popularizar-se na década de 1960 até converter-se, hoje, em um conceito utilizado 
em âmbitos muito diversos, como na saúde, na saúde mental, na educação, na economia, na política e no mundo dos serviços em geral (GÓMEZ,1998).

Para Arostegui (1998) em um primeiro momento, a expressão qualidade de vida aparece nos debates públicos em torno do meio ambiente e da deterioração das condições de vida urbana. Durante a década de 1950 e início da década de 1960, o crescente interesse por conhecer o bem-estar humano e a preocupação pelas conseqüências da industrialização da sociedade fazem surgir a necessidade de medir esta realidade através de dados objetivos. Nas ciências sociais inicia-se o desenvolvimento de indicadores sociais e estatísticos que permitem medir dados e feitos vinculados ao bem-estar social de uma população. Estes indicadores tiveram sua própria evolução, sendo que, inicialmente, há referência das condições objetivas do tipo econômico e social, e em um segundo momento passa-se a contemplar elementos subjetivos de tais indicadores.

O mesmo autor explica que o desenvolvimento e aperfeiçoamento dos indicadores sociais, em meados dos anos de 1970 e início dos anos de 1980, provocaram o processo de diferenciação entre estes indicadores sociais e a qualidade de vida. A expressão começa a definir-se como conceito integrador que compreende todas as áreas da vida, revelando-se com um caráter multidimensional, fazendo, portanto, referência tanto a condições objetivas como a componentes subjetivos da vida das pessoas. A primeira inclusão do termo na revista norteamericana, "Social indicators research", em 1974 e na "Sociological abstracts", em 1979, contribuiu para a sua difusão teórica e metodológica, confirmando assim, a década de 80, como a de decolagem definitiva da investigação em torno do tema.

Explica ainda Arostegui (1998), que transcorridos 20 anos, ainda existe uma falta de consenso sobre a definição do constructo e sua avaliação. Assim, embora 
historicamente existam duas aproximações básicas, aquela que concebe a qualidade de vida como uma entidade unitária, e a que a considera como um constructo composto por uma série de domínios, Felce e Perry (1995), encontraram ainda diversos modelos conceituais de qualidade de vida. Às três conceitualizações propostas por Borthwick-Duffy (2002), foi acrescentada uma quarta. Segundo esta, a qualidade de vida foi definida como a qualidade das condições de vida de uma pessoa, como a satisfação experimentada pela pessoa em certas condições vitais, como a combinação de componentes objetivos e subjetivos. Quer dizer, qualidade de vida é definida como a qualidade das condições de vida de uma pessoa, associada à satisfação que esta experimenta, refletida por uma escala de valores, aspirações e expectativas pessoais.

A avaliação do conceito apresenta uma situação parecida. Para Dennis, Williams, Giangreco e loninger (1994), os enfoques de investigação deste conceito são variados, mas poderiam englobar-se em dois tipos: o enfoque quantitativo e o qualitativo. O quantitativo aparece com o propósito de operacionalizar a qualidade de vida e para isso, estudam-se diferentes indicadores tais como os sociais, os psicológicos e os ecológicos.

Os indicadores sociais referem-se a condições externas relacionadas à questão da saúde, do bem-estar social, da amizade, do padrão de vida, da educação, da segurança pública, do ócio, da vizinhança, da moradia, entre outros. Os indicadores psicológicos medem as reações subjetivas do indivíduo à presença ou ausência de determinadas experiências vitais e os ecológicos medem o ajuste entre os recursos do sujeito e as demandas do ambiente. E finalmente, o enfoque qualitativo que adota uma postura de escuta à pessoa enquanto ela relata suas 
experiências, seus desafios e problemas; procura estudar como os serviços sociais podem Ihe apoiar eficazmente.

No presente trabalho optamos por um enfoque qualitativo, uma vez nos interessa saber, do ponto de vista das mulheres que se submeterem à histerectomia por complicações do parto, como isso afeta o seu cotidiano e as suas vidas.

Segundo Gómez (1998) apesar desta aparente falta de acordo entre os investigadores sobre a definição de qualidade de vida e a metodologia utilizada para seu estudo, o conceito teve um impacto significativo na avaliação e planejamento de serviços durante os últimos anos. Para Schalock (1996), a investigação sobre qualidade de vida é importante porque o conceito está emergindo como um princípio organizador que pode ser aplicável para a melhoria da sociedade, que está submetida a transformações sociais, políticas, tecnológicas e econômicas. Não obstante, a verdadeira utilidade do conceito é percebida, sobretudo nos serviços humanos, como imersos em uma "revolução de qualidade" que propugna o planejamento centrado na pessoa e a adoção de um modelo de apoio e de técnicas de melhoria da qualidade.

Schalock (1997) afirma que de 1987 a 1997 as investigações sobre qualidade de vida foram aumentando progressivamente em diferentes âmbitos do fazer profissional e científico. Entre as ciências da saúde, os avanços da medicina possibilitaram prolongar notavelmente a vida, gerando um incremento importante para aqueles com enfermidades crônicas, e isso levou à utilização de um novo termo: qualidade de vida relacionada à saúde.

Atualmente numerosos trabalhos de investigação científica empregam 0 conceito de qualidade de vida como um modo de referir-se à percepção que tem o paciente dos efeitos de uma determinada enfermidade ou da aplicação de certo 
tratamento, em diversos âmbitos de sua vida, especialmente em relação às conseqüências sobre seu bem-estar físico, emocional e social.

As tradicionais medidas de morbi-mortalidade estão dando passo a esta nova maneira de valorar os resultados das intervenções, e nesta linha, a meta da atenção à saúde está se orientando não somente para eliminação da enfermidade, mas também à melhoria da qualidade de vida do paciente. Atualmente há importantes trabalhos realizados sobre intervenções com pessoas com câncer, AIDS, asma e esclerose múltipla, entre outras (SCHALOCK, 1997).

Neste sentido, para Gómez (1998), o conceito pode ser utilizado para uma série de propósitos, incluindo a avaliação das necessidades das pessoas e seus níveis de satisfação, para a avaliação dos resultados dos programas e serviços humanos, para direção e guia da provisão destes serviços e na formulação de políticas nacionais e internacionais dirigidas à população geral e a outras mais específicas, como a população com incapacidades.

Segundo Ruffino - Netto (1992) de acordo com a forma de se refletir sobre o homem como um ser bio-psico-social, vamos observar uma diversidade de situações. O homem, além de reproduzir como os animais, é capaz de produzir suas necessidades, de incorporar experiências e conhecimentos para a educação e para a cultura; ele se humaniza à medida que altera a natureza e altera a si mesmo, num processo permanente de mútua transformação; desenvolve o raciocínio; produz artefatos, instrumentos, conhecimentos e senso comum.

Para falar de qualidade de vida, é necessário ver o homem dentro de sua sociedade, e assim, a sua condição de vida, seus determinantes sociais, econômicos e políticos, isto porque as experiências humanas são formadas pela 
história, pelos relacionamentos, pela política, pela estrutura social, pelo gênero e pela cultura.

Dependendo da perspectiva que se apresenta, têm-se definições diferentes de qualidade de vida, pois este é um "conceito multifatorial, que envolve a sensação de bem-estar e satisfação do indivíduo, sua condição física, seu estado emocional, sua função intelectual, seu desempenho no trabalho e sua participação social (CHORAYEB,1996).

Forattini (1991) chama atenção de que é fácil entender os obstáculos que se apresentam para alcançar uma conceituação precisa do que deve ser qualidade de vida, pois o caráter subjetivo lhe é inerente.

As dificuldades de conceituar a qualidade de vida somam-se às de sua mensuração. Como os autores dão uma diversidade de definições, atualmente a maioria deles a definem com referência ao bem-estar das pessoas (CELLA e TULSKY,1997). Associadas a tais dificuldades, surgem aquelas relacionadas à natureza da qualidade de vida, ou seja, das suas dimensões subjetivas e objetivas. As definições que trazem as dimensões subjetivas colocam-se como mais globais, e estão baseadas no bem-estar, em dois marcadores básicos: a satisfação e a felicidade. A dimensão objetiva refere-se às condições materiais de vida, ao nível de vida e inclui fatores que determinam ou influem sobre a percepção que tem o sujeito sobre a presença ou não de sintomas e funcionamento físico.(SHALOCK, 1997).

A questão da objetividade pode referir-se ao velho problema sobre quem faz a avaliação: se um observador externo ou a própria pessoa (SHALOCK,1997). Isto é particularmente importante no que se refere à qualidade de vida em relação com a saúde, e, especialmente, na resolução dos problemas metodológicos de sua avaliação. Nos últimos anos, parece muito mais útil o estudo de sua dimensão 
subjetiva, sua natureza psicológica, avaliada pelo próprio indivíduo. As condições objetivas se refratam através das aspirações, das expectativas, de referências vividas e conhecidas, das necessidades e valores das pessoas, de suas atitudes e emoções, e é através deste processo que se converte em bem-estar subjetivo. Não basta com que aumentem os indicadores socioeconômicos para gerar satisfação, bem-estar e felicidade. Está claro que nem sempre o sofrimento ou a felicidade está determinado pelo nível de vida: a opulência social e o consumismo de bens não significam, definitivamente, qualidade de vida (DICKEY, 1996).

Portanto, a abordagem que lida com as dimensões subjetivas da qualidade de vida, especialmente aquelas que buscam apreender o bem-estar do indivíduo e sua satisfação de vida, foi a perspectiva escolhida para entender se a histerectomia decorrente de complicações de parto interfere naquilo que as mulheres, nessa condição, conceituam como qualidade para as suas vidas.

\subsection{Interacionismo Simbólico}

Ao buscar um referencial teórico que possibilitasse a interpretação do significado que as mulheres submetidas à histerectomia por complicação durante o trabalho de parto e parto, dão a esta experiência, encontramos no interacionismo simbólico o respaldo que necessitávamos.

O comportamento humano, nesta perspectiva, é entendido como um ato social e não meramente uma resposta do indivíduo a si mesmo e a outras pessoas que lhe respondem.

O interacionismo simbólico, cujos fundamentos são atribuídos a George Herbert Mead, foi desenvolvido quando o mesmo era professor de filosofia na 
Universidade de Chicago. Suas bases foram assentadas na perspectiva da psicologia social que enfoca a natureza da interação que ocorre entre as pessoas.

Grande parte da influência de Mead no interacionismo simbólico se deu pela disseminação de seus pensamentos entre seus alunos, que publicaram suas conferências e notas realizadas em sala de aulas, uma vez que Mead teve apenas alguns de seus trabalhos publicados.

Um destes alunos, Herbert Blumer ocupou o seu lugar na Universidade de Chicago, depois de sua morte, ficando atribuída a ele grande parte do desenvolvimento do interacionismo simbólico (STRAUSS, 1997). Apesar de vários estudos na Universidade de Chicago terem usado a abordagem interacionista, as orientações metodológicas do interacionismo foram desenvolvidas por Blumer, o que contribuiu para direcionar muitas questões cruciais que estavam somente implícitas no pensamento de Mead. Blumer também tratou de explicitar outros tópicos críticos com os quais outros estudiosos ainda não haviam se preocupado.

A relevância dos trabalhos de Mead, em particular a sua teoria dos símbolos, é destacada em três aspectos:

- a historicidade do indivíduo inerente à auto consciência, significa dizer que há uma anterioridade histórica da sociedade sobre a pessoa individual,

- $\quad$ a formulação de uma hipótese naturalística acerca do desenvolvimento do indivíduo auto-consciente que faz a partir da matriz das relações sociais,

- na formação do eu, a sua função essencial se destina à adoção de papéis e à internalização do sociocultural.

Por meio destes três pontos, a superação da autonomia entre indivíduos e sociedade articula-se em uma série de formulações teóricas susceptíveis de dar 
lugar à investigação da realidade social, e é, justamente nesta possibilidade de expansão onde reside a validade e o valor científico de uma teoria (MEAD,1982).

Tal doutrina não só representa a formulação de um detalhado modelo teórico de funcionamento do indivíduo social dentro do grupo, mas também permite superar toda consideração abstrata do indivíduo e sociedade, proporcionando uma série de hipóteses valiosas sobre o condicionamento cultural da personalidade do mesmo.

O legado teórico de Mead traz como argumento básico, que é no espaço interativo que se enraízam os símbolos e seus significados, e é por aí que se forma a mente/espírito, sendo a mesma conformada no processo de comunicação. Explica Mead, que os indivíduos não existem como tal, mas sim como um self que transita um espaço social e que a sociedade se apresenta como fundo.

Esclarece ainda, que desde o nascimento a criança está imersa em um meio sociocultural diferenciado, pois pertence a um povo, a uma época, a uma classe, ou melhor, pertence a um grupo dotado de especificações histórico-sociais concretas. Os papéis que introjeta, que assume no processo de formação de sua individualidade são aqueles que o ambiente lhe oferece. $E$ as pessoas que o rodeiam são portadoras de formas específicas de cultura. Os papéis que assume correspondem aos próprios padrões culturais de seu setor social. Portanto, o indivíduo não internaliza uma sociedade em abstrato, mas reproduz em si mesmo uma estrutura social concreta, historicamente determinada.

E dessa forma, Mead (1969) afirma que essa introjeção de papéis é substancial para o surgimento da autoconsciência, ou seja, não se chega a ser simplesmente uma pessoa, um ser consciente da própria individualidade, mas o despertar gradual da autoconsciência corresponde precisamente ao despertar 
gradual de todas aquelas especificações concretas que o caracteriza como membro do grupo. Portanto, o eu está recortado no substrato das relações sociais.

Por outro lado, Mead interessou-se pelos símbolos lingüísticos, visto que para ele tais símbolos medeiam as interações sociais, os modos de comportamentos e de ações de mais de um indivíduo. Neste sentido, sua preocupação fundamental se assentava na ação comunicativa onde, além de sua função de entendimento, a linguagem joga um papel de coordenação das atividades orientadas para fins de distintos sujeitos, além de seu papel na intermediação da socialização dos mesmos sujeitos.

Para Mead, a sociedade humana, tal como a conhecemos, não poderia existir sem as mentes e os seres. Ele insiste que as mentes racionais e os seres conscientes emergem somente em sociedade por serem produto da interação social e, especialmente, da comunicação simbólica por meio da linguagem.

As coisas que existem na natureza não são objetos até que sejam descobertas e nomeadas, e as coisas que não existem na natureza podem ser objetos se existirem na mente dos sujeitos. Neste sentido, a cultura de todo grupo social está constituída de seu mundo de objetos significativos e a mente de cada pessoa está constituída de seu mundo próprio de objetos significativos.

Mead considera que homem é um ator, não um reator. $\mathrm{O}$ ato social tem um conceito amplo, que pode abranger quase todos os outros processos psicológicos e sociais. O ato humano pode ser breve ou pode ser a realização de um plano de vida. Os atos começam com um impulso, envolvem percepção e atribuição de significado, repetição mental e ponderação de alternativas e consumação final. 
Coube a Blumer a sistematização dos pressupostos básicos da abordagem interacionista, até mesmo a criação do termo interacionismo simbólico, em 1937. Assim, Blumer mostra e argumenta os aspectos mais importantes da interação humana, onde tratou de ser o mais fiel possível ao pensamento de Mead. Portanto, Blumer trata da natureza da interação humana, da natureza da sociedade e da vida em grupo, da natureza dos objetos da ação humana e da ação coletiva (HAGUETTE, 2003).

Para Blumer (1969), o interacionismo simbólico apóia-se em três premissas:

1. $O$ ser humano atua em relação às coisas baseando-se no significado que estas têm para ele. Estas coisas incluem tudo o que o ser humano pode notar em seu mundo: objetos físicos, outros seres humanos, categoria de seres humanos, tais como amigos, instituições, idéias, guia como honestidade, atividades de outros como petições e diversas outras situações que o indivíduo pode encontrarse em sua vida diária.

2. O significado de tais coisas se deriva de, ou surge da interação social que cada um tem com seus semelhantes. Deste modo, os significados das coisas são produtos sociais, ou criações que são formadas, apoiadas ou modificadas através das atividades definidoras das pessoas quando elas interagem com as outras.

3. Esses significados são manipulados e modificados através de um processo interpretativo usado pela pessoa ao lidar com as coisas que encontra. Dessa forma, a pessoa não aplica o significado derivado apenas da interação, mas faz uso deste significado por meio de um processo de interpretação, o qual ocorre em duas etapas: 
Na primeira, a pessoa indica para si mesma as coisas na direção em que ela está atuando, apontando para si mesma as coisas ou aquilo que têm significado dentro de um processo social internalizado, no qual ela interage consigo mesma. Em seguida, em virtude deste processo de comunicação consigo mesma, a interpretação se torna uma questão de dirigir os significados.

Buscar apreender o significado da histerectomia decorrente de complicações do parto na vida das mulheres que vivenciam esta situação e as relações que elas estabelecem neste processo de significação foi dar oportunidade a elas de analisar o seu cotidiano e avaliar como tem sido a qualidade de suas vidas. 


\section{CAPITULO III: O Desenho Metodológico}

\subsection{O Contexto do Estudo}

Antes de iniciar a descrição do local onde foi realizado o presente estudo, é conveniente que primeiro se conheça o Sistema Nacional de Saúde Mexicano, sua forma de organização e seu esboço geral, de onde origina o Programa Nacional de Saúde, para compreender melhor o contexto onde se realizou o estudo.

O Sistema Nacional de Saúde Mexicano está constituído por dois esquemas de atendimento, o público e privado. O Sistema Nacional de Saúde e de Segurança Social dá cobertura aos trabalhadores da economia formal (58 milhões no ano 2000) que é composta por várias instituições, cada uma das quais se financia com a contribuição dos patrões, empregados e governo.

O Instituto Mexicano de Seguro Social (IMSS) é a instituição maior, com cerca de $80 \%$ dos assegurados; depois dele vêm o Instituto de Segurança e Serviços Sociais dos Trabalhadores do Estado (ISSSTE), Petróleos Mexicanos (PEMEX), as Forças Armadas e a Marinha (SNS,2001)

O ordenamento jurídico do setor apóia-se em duas leis gerais: a Lei Geral de Saúde e a Lei do Seguro Social. Um número importante de Estados conta com Lei Estatal de Saúde. No marco do Tratado de Livre Comércio da América do Norte realizam-se intercâmbios e convocam-se grupos intergovernamentais dos EUA, 
México e Canadá para a harmonização da legislação de produtos e serviços relacionados com a saúde.

A Secretaria de Saúde do México (SSA) é a instituição reitora do Sistema Nacional de Saúde; os serviços privados de saúde estão bastante fragmentados e oferecem atenção de qualidade e preços desiguais.

As Organizações não Governamentais alcançam um importante desenvolvimento em certas áreas como a da saúde reprodutiva, da violência intrafamiliar, da AIDS e de outras enfermidades, trabalhando cada vez mais de modo coordenado através de redes (Sistema Nacional de Saúde, 2001-2006).

A Organização das Ações de Regulação Sanitária se faz por meio da Secretaria de Saúde (SSA), cuja instituição é responsável por fiscalizar a qualidade, a segurança e a eficácia dos medicamentos, de reativos, de imunobiológicos e de equipes. Tem a seu cargo o registro nacional de todos os insumos, a regulamentação da comercialização mediante a expedição de licenças e registros sanitários, e fiscaliza ainda, a propaganda que aparece nos meios de difusão. A verificação, o controle analítico e a avaliação dos medicamentos e insumos se realizam tanto nos laboratórios da SSA como nos denominados "terceiros autorizados". Os serviços de fornecimento de água potável e saneamento são responsabilidade dos municípios.

Cada estado tem sua própria lei ou código de água potável e uma Comissão de Água que apóia, técnica e financeiramente, aos municípios. O uso de substâncias químicas é autorizado pela Direção Geral de Saúde Ambiental da SSA e há uma Comissão Intersecretarial para o controle do uso de praguicidas, fertilizantes e substâncias tóxicas, encarregada da regulação, comercialização e o controle dos efeitos sobre o ambiente e a saúde. Fiscaliza a qualidade do ar em 14 cidades do 
país. A Direção Geral de Qualidade Sanitária de Bens e Serviços, em colaboração com o Laboratório Nacional de Saúde Pública, está a cargo do monitoramento de produtos e serviços relacionados com a saúde (Sistema Nacional de Saúde 20012006).

A SSA é a instituição responsável por oferecer os serviços de saúde pública, apoiada pelas instituições de seguro social, particularmente o IMSS, com programas de saúde comunitária que incluem ações de promoção de saúde e prevenção de enfermidades em lares, escolas e centros de trabalhos. A SSA e a Secretaria de Educação Pública desenvolvem um programa de saúde escolar e do adolescente que abrange cerca de 30.000 escolas e executam a iniciativa de escolas promotoras de saúde. A informação sobre a mortalidade constrói-se com os certificados de falecimento, que é o instrumento legal obrigatório para a declaração de morte dos cidadãos, desde 1998.

O acesso a serviços de rede de esgoto e eliminação de excreta era de $76 \%$ da população nacional em 2000 , $90 \%$ em população urbana e $37 \%$ em população rural. Existe uma norma oficial para o manejo dos resíduos hospitalares, e também um comitê de infecções nosocomiais em cada hospital, ambos regidos por uma norma técnica elaborada pela Secretaria de Saúde (Sistema Nacional de Saúde, 2001-2006).

A organização da atenção às pessoas nos serviços públicos de saúde está estruturada por níveis de atenção. O primeiro nível de atenção inclui ações de promoção à saúde, prevenção de enfermidades e atenção ambulatorial à morbidade mais freqüente (centros de saúde e clínicas). O segundo nível de atenção é onde se oferece a atenção de especialidades básicas em hospitais gerais ou de especialidade. Oferece-se atenção ambulatorial e de hospitalização e, geralmente, 
dispõe-se de serviços de apoio diagnóstico de imagem e laboratório. O terceiro nível de atenção é aquele em que se realizam cuidados especializados de maior complexidade, assim como investigações clínicas e básicas, a cargo de médicos especialistas com apoio de enfermaria especializada e outros profissionais.

\section{Caracterização do Município}

A cidade de Nezahualcóyotl localiza-se na região central do país, no estado do México, e forma parte da zona metropolitana da cidade do México. Encontra-se a uma altitude de $2.220 \mathrm{~m}$, é cabeceira municipal de recente criação, que se assenta no que antigamente foi o lago do Texcoco. É um dos principais centros manufatureiros do Estado, com uma indústria altamente diversificada, e também com maior população. Seu crescimento e desenvolvimento têm sua origem na década de 1950, quando se proibiu a criação de novos assentamentos de população e indústrias no Distrito Federal, e por isso este centro foi receptor dos mesmos.

É sede da diocese do mesmo nome, criada em 1979. Sua população é constituída por 1.225.972 habitantes. A densidade populacional é de 19.325 habitantes por $\mathrm{km}^{2}$ (Censo de Población e vivienda, 2000)

A pirâmide populacional apresenta 595.585 homens e 630.387 mulheres, e uma base larga com predomínio dos grupos de crianças de 0 a 14 anos, que corresponde aos $34,71 \%$ do total da população. Deste modo, $59,68 \%$ da população é representada pelo grupo de 15 a 65 anos, e 5,61\% por pessoas com mais de 65 anos.

No Município de Nezahualcoyotl, $84,41 \%$ da população localiza-se em áreas urbanas, como resultado dos movimentos migratórios para as grandes cidades, tendo como destino os municípios do interior da Zona Metropolitana da Cidade do 
México. Este município faz limite com o Distrito Federal, juntamente com municípios do estado do México, Ecatepec, Chimalhuacan, os Reyes a Paz e Texcoco (fig 1).

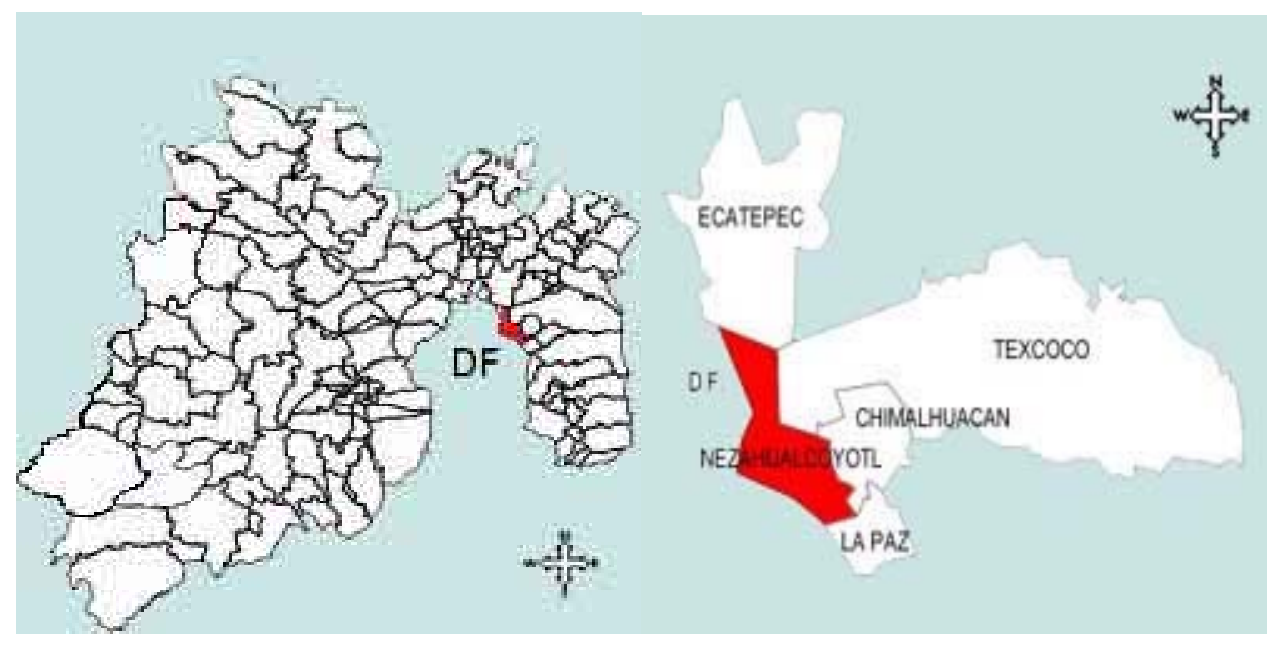

Figura No. 1-Mapa representativo do Estado do México, Distrito Federal, município Nezahualcoyotl

A atenção médica neste município conta com 37 unidades médicas, com 196 leitos, 636 médicos registrados e 887 enfermeiras, o que corresponde a 33.134 habitantes por unidade médica, 1.927 habitantes por médico e 1.382 habitantes por enfermeira.

Em relação à esperança de vida ao nascer, nos últimos anos obteve-se um incremento próximo a 5 anos em cada geração, o que indica que a cada 20 anos, o tempo que um recém-nascido viverá será maior. Para o ano de 1995 a expectativa de vida de um recém-nascido era de 73,3 anos, em geral, sendo em média de 70,0 anos para os homens e 76,6 para as mulheres.

Estas expectativas não são aplicáveis de maneira homogênea na região, uma vez que existem municípios com esperança de vida menor como é o caso do Joquicingo, Nextlalpan, Nopaltepec, Villa Guerreiro, Villa Vitória e São Felipe do 
Progresso, que têm uma probabilidade de vida entre os 67,13 e 73,09 anos. Por outro lado, encontramos municípios como Cuautitlan, Jaltenco, Tlalnepantla, Papalotla, Chalco, Ecatepec, os quais têm, atualmente, uma alta esperança de vida, que fica entre os 71 e 74 anos. É importante destacar que, embora esses municípios mexicanos se vejam favorecidos por estas probabilidades, elas ainda estão distantes daquelas alcançadas em países desenvolvidos, como o Japão, onde a expectativa de vida é de 79 anos (DIAGNÓSTICO DE SAÚDE, 2000)

O índice de analfabetismo no município é da ordem de $6 \%$ da população.

Segundo a classificação do grau de marginalização dos municípios, com apoio nos indicadores elaborados pelo Conselho Nacional de População, observouse que a população deste município se encontra em um nível baixo.

Apesar disso, Nezahualcoyotl, por sua grande extensão, tem a maioria de suas áreas ocupadas por assentamentos humanos, onde se apresentam altas as taxas de marginalidade, fazendo com que o município seja considerado de alta periculosidade, e onde se identificam sérios problemas relacionados ao alcoolismo, dependência de drogas e vandalismo.

\section{Local de estudo}

Este estudo foi desenvolvido no Hospital Geral Dr. Gustavo Baz Prada, da SSA da cidade Nezahualcóyotl, Município do Estado do México, inaugurado em 25 de Agosto de 1987 pelo governador do estado do México, Lic. Mario Ramón Beteta. Está integrado ao grupo de hospitais do Instituto de Saúde do Estado do México da Secretária de Saúde.

O Hospital Geral Dr. Gustavo Baz Prada conta com as quatro especialidades médicas básicas: medicina interna, cirurgia geral, pediatria e gineco-obstetrícia. Faz 
parte dos hospitais de reconstrução e descentralização dos serviços de saúde, sendo moderno e funcional. A equipe de profissionais do hospital, que dá cobertura de atendimento à população mexicana.é nova e de alta qualidade.

O hospital oferece atenção à Cidade Nezahualcoyotl, sobretudo à população aberta que não conta com prestações de serviço de outras instituições de saúde. Encontra-se integrado ao sistema de saúde independente do Instituto de Saúde do Estado do México (figura2). Foi criado pela Secretaria de Saúde com base nas necessidades da população, pois contava-se apenas com o Hospital da Perla para atendimentos à população sem seguridade social aberta e que requeria atenção médica.
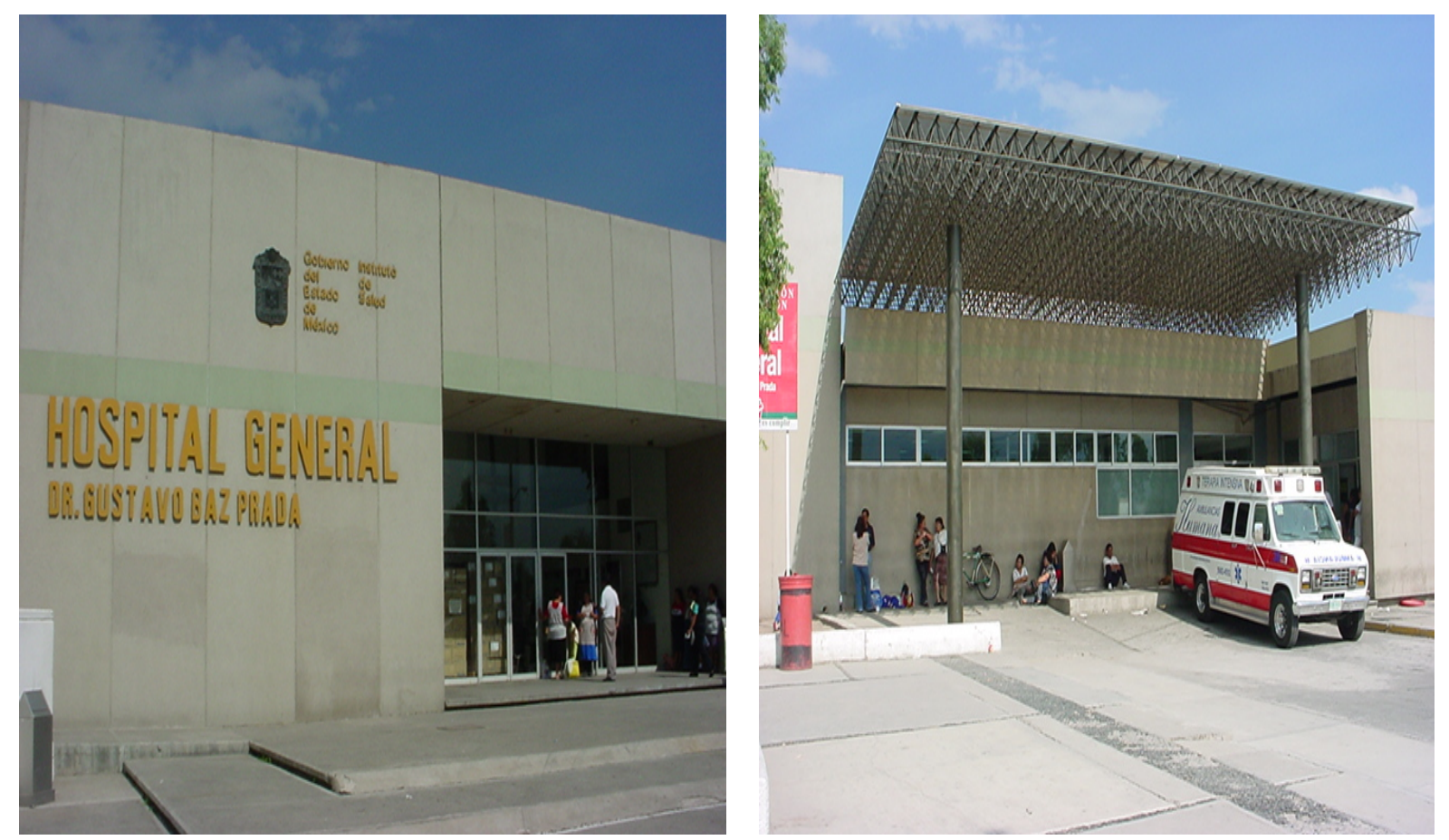

Figura N²- Fotos da fachada do Hospital General Dr Gustavo Baz Prada/ Nezahualcoyotl 
O Departamento de Enfermagem comemora o aniversário do hospital através de trabalhos de investigação, explorando temas médicos e culturais expostos pelo pessoal da Instituição e por distintos convidados.

O Hospital Geral Dr. Gustavo Baz Prada é uma unidade de segundo nível de atenção, composto por quatro especialidades médicas básicas e algumas especialidades de apoio. É constituído por144 leitos ocupados e 63 vagos, sendo que 37 leitos se destinam à ginecologia e obstetrícia, assim distribuídos: 12 leitos para gravidez de alto risco, 12 leitos de puerpério fisiológico, 12 leitos de puerpério cirúrgico e 1 leito para isolamento. O número de partos atendidos por ano tem aumentado muito nestes quatro últimos anos, totalizando cerca de 500 partos/mês. (figura 3)

A unidade assistencial foi criada para contribuir com as demandas de atenção médica da população aberta, mediante ações que favoreçam a saúde individual e coletiva para os recursos de saúde existentes.

Sua missão é proporcionar com prontidão, eficácia e qualidade, serviços de saúde à população aberta do Estado do México, para contribuir com o exercício pleno de sua capacidade, assim como para o melhoramento do desenvolvimento social.

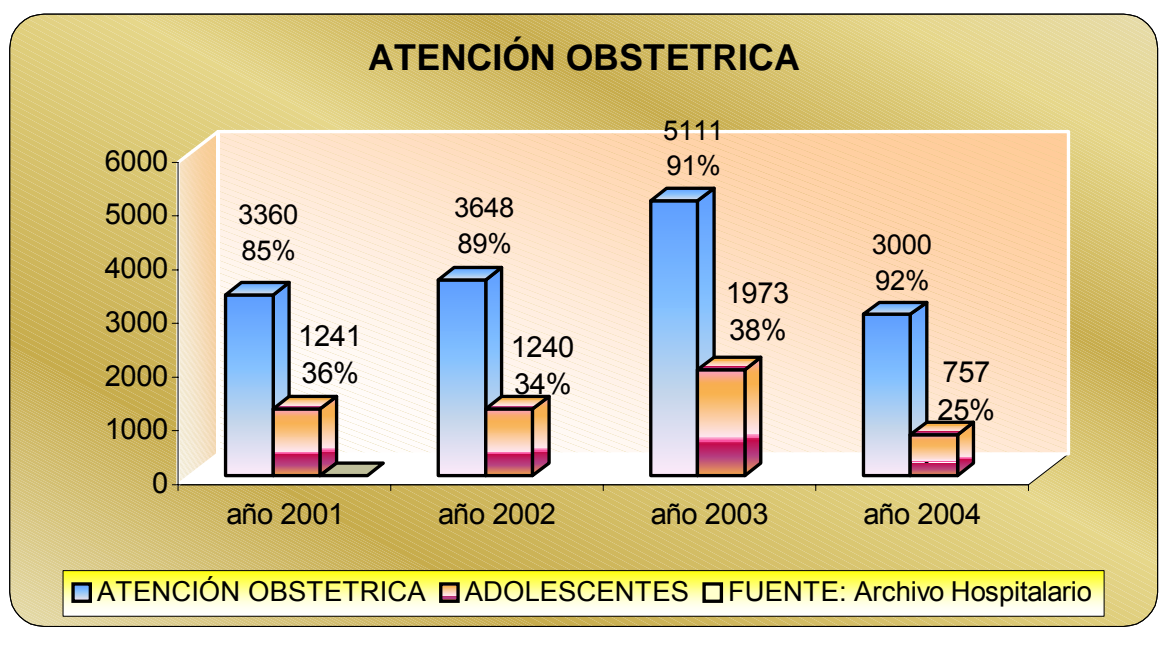

Figura N³- Distribuição do número de partos atendidos no Hospital General Dr Gustavo Baz Prado/ Nezahualcoyotl/2001-2004 
Apresenta como objetivo a obtenção da satisfação total do paciente e do servidor público na atenção médica, através de uma relação de respeito e qualidade.

O hospital apresenta, dentro de suas políticas de atenção, as seguintes metas:

- Favorecer as ações adequadas de saúde individual e coletiva. Incrementar os programas de higiene e melhoramento do ambiente.

- Preservar e melhorar a saúde mental da população, especialmente de jovens e meninos.

- Cumprir com os programas prioritários estabelecidos pelo Instituto de Saúde do Estado do México.

\subsection{Sujeitos do Estudo}

Esta pesquisa foi realizada com 10 mulheres histerectomizadas, em decorrência de complicações no trabalho de parto e parto, no período de 2003-2004

Para a definição do número de sujeitos foram tomadas como base às orientações de Minayo (2000), quando diz que uma amostra ideal é aquela que privilegia os sujeitos sociais que detêm os atributos que se pretende conhecer; aquela que por meio de um número suficiente de entrevistas fornece informações relevantes que conduzam à formulação de categorias e que seja capaz de refletir a totalidade nas suas dimensões.

Portanto, o tamanho da amostra teve como base a saturação dos dados, a qual, segundo Minayo (2000), considera o número de sujeitos suficiente quando for permitido uma certa reincidência das informações, porém sem desprezar informações ímpares, cujo potencial explicativo tem que ser levado em conta. Como 
reforça a autora, na busca qualitativa preocupamo-nos menos com a generalização e mais com o aprofundamento e abrangência da compreensão.

Este estudo foi submetido à análise e aprovação pelo Comitê de Ética e Pesquisa do Hospital Geral Dr. Gustavo Baz Prada, da Secretaria de Saúde do Estado. de México (anexo A).

As mulheres elegíveis para o estudo foram contatadas e convidadas a participar. Aquelas que aceitaram participar, foram agendados horários para a realização das entrevistas, de acordo com a preferência das mesmas. É importante assinalar que todas as mulheres que foram convidadas a participar do estudo estiveram de acordo, assinando o termo de consentimento livre e esclarecido. (APÊNDICE A)

Com base na resolução 196/96 sobre pesquisas com seres humanos, foram feitos os esclarecimentos necessários sobre a justificativa, objetivos e metodologia da pesquisa; tendo as mulheres a liberdade de participar ou não no estudo, com a garantia de esclarecer dúvidas antes ou durante o curso da investigação, assim como a garantia do sigilo dos dados fornecidos. Foi ainda dada a liberdade para que elas decidissem continuar ou interromper sua participação, no momento que desejassem.

Os critérios de inclusão das participantes foram os seguintes: idade de 15 a 30 anos, independente da paridade, que tivessem sido atendidas no Hospital Geral Gustavo Baz Prada, e submetidas à histerectomia por complicação no trabalho de parto e parto, e residissem na cidade de Nezahualcoyotl. A eleição para a faixa etária das mulheres que foram investigadas se deu por ser este o período de maior fecundidade das mulheres, em geral, e do México, em particular. 


\subsection{Coleta de dados}

A coleta de dados se fez por meio de entrevistas semi-estruturadas gravadas e transcritas em sua totalidade, que segundo Minayo (2000) combinam perguntas fechadas ou estruturadas e abertas, onde o entrevistado tem a possibilidade de discorrer sobre o tema proposto, sem respostas ou condições pré-fixadas pelo pesquisador. Triviños (1987) enfatiza que a entrevista é um dos principais meios que tem o investigador para realizar a coleta de dados.

Este autor orienta que a entrevista semi-estruturada é aquela que parte de certos questionamentos básicos, sustentados em teorias e hipóteses que interessam à pesquisa e que, em seguida, oferece amplo campo de interrogação, fruto de novas hipóteses que vão surgindo à medida que se recebem as respostas do informante. Desta maneira, o informante, seguindo espontaneamente a linha de seu pensamento e de suas experiências dentro do foco principal colocado pelo investigador, começa a participar na elaboração do conteúdo da pesquisa.

Minayo (2000) observa que a busca de informações pode ser feita verbalmente ou por escrito, mas tradicionalmente inclui a presença ou interação direta entre o pesquisador e os atores sociais é complementada por uma prática de observação participante. Sua qualidade consiste em enumerar de forma mais abrangente possível as questões que o pesquisador quer abordar no campo, a partir de suas hipóteses ou pressupostos, advindos, obviamente, da definição do objeto de investigação.

As entrevistas realizaram-se no período de outubro de 2003 a julho 2004, no local de escolha das participantes. Nove participantes foram entrevistadas em seu domicílio, no período da manhã e da tarde e uma das entrevistadas preferiu que as 
entrevistas fossem realizadas no hospital onde trabalhava. Foram efetuadas quantas entrevistas fossem necessárias.

As entrevistas tiveram uma duração entre 30 e 120 min e foram conduzidas pela pesquisadora. $\mathrm{O}$ treinamento do pesquisador e o teste piloto sobre a adequação das perguntas foram realizados em mulheres com histerectomia por outras causas.

$\dot{E}$ importante apontar que, apesar de termos um roteiro prévio para as entrevistas, as mesmas foram conduzidas de forma a permitir a expressão livre das questões norteadoras e sempre com a preocupação de não impor pré-conceitos e definições acerca do processo que a mulher foi submetida à histerectomia. Procuramos durante a entrevista e por meio da observação, captar informações sobre o contexto doméstico, familiar, observar seus comportamentos e da família. A observação era enriquecida à medida que se dava nova entrevista, pois a nosso olhar foi se tornando mais específico e acurado Procedemos a notas de campo, quando necessário.

Não se observou nenhuma dificuldade para a gravação das entrevistas, pois expressaram livremente sobre as questões feitas diante do gravador. Observamos que principalmente depois da segunda visita, elas se mostraram mais seguras e confiantes para conversar.

Foram realizadas em torno de três entrevistas para cada mulher.

Ao elaborar suas falas, a respeito do tema proposto, as entrevistadas realizaram um trabalho de recordar, de procurar na memória algo de suas vivências passadas que explicassem as situações que foram solicitadas. Quiroz (1987) diz que por ser um modo de contar, e um modo de lembrar, a entrevista produz sempre uma 
interpretação da pessoa que relata representando, assim, uma articulação possível de pedaços de experiência e conhecimentos. Por tais características, a entrevista requer, na sua produção e análise, procedimentos apropriados (APÊNDICE B).

As entrevistas foram realizadas tendo como base as seguintes questões:

1 Você poderia me contar como foi para você ter que tirar o seu útero?

^ O que significa ou significou isto para você?

1 Como você se percebe agora, depois dessa cirurgia?

1 Mudou alguma coisa na sua vida depois da cirurgia?

1 Você sente que a cirurgia trouxe alguma alteração no seu modo de vida, no seu modo de se relacionar com as pessoas, com alguém em particular, com você mesma?

^ Teria mais alguma coisa a acrescentar, que você gostaria de falar ou perguntar?

\subsection{Tratamento e análise dos dados}

Os dados coletados das entrevistas foram submetidos à análise de conteúdo e utilizada a técnica de análise temática. Esta técnica busca descobrir de maneira objetiva e sistemática o significado das vivências dos sujeitos estudados, buscando a compreensão da realidade social onde o fenômeno se dá.

O método consiste em se proceder à classificação e codificação de diversos elementos de uma mensagem em categorias, com o fim de buscar unidades de significação que levem a um sentido para aquilo que está sendo dito pelos atores sociais. 
A identificação das unidades temáticas ou de significância possibilitou, no presente trabalho, uma melhor compressão do significado da perda do útero na vida das mulheres e como isto interferiu na qualidade de suas vidas.

A análise temática é um conjunto de técnicas de análise das comunicações, que visa a obter, por meio de procedimentos sistemáticos e objetivos, a descrição do conteúdo das mensagens e de indicadores que permitam identificar conhecimentos relativos às condições de produção e recepção dessas mensagens. (BARDIN, 1979).

Para a operacionalização do método, o pesquisador, em seu processo de análise deverá estar atento a contemplar os seguintes aspectos:

- Objetividade refere-se à explicitação das regras e dos procedimentos utilizados em cada etapa da análise de conteúdo. Em cada momento do processo, o pesquisador deverá tomar decisões sobre quais categorias usar, como distinguir as categorias, quais critérios deve utilizar para registrar e codificar o conteúdo. Isto implica que tais descrições se baseiem em um conjunto de normas, para minimizar a possibilidade de que os resultados sejam mais um reflexo da subjetividade do pesquisador do que uma análise de conteúdo de determinado documento.

Uma análise de conteúdo categorial deve cumprir os seguintes requisitos:

1 Homogeneidade: não misturar critérios de classificação;

Exaustividade: classificar a totalidade do texto;

1 Exclusão: um mesmo elemento não pode ser classificado em mais de uma categoria;

1 Objetividade: codificadores diferentes devem chegar aos mesmos resultados. 
Sistematização refere-se à inclusão do conteúdo ou categorias de um texto de acordo com regras coexistentes e sistemáticas. Isso significa que para tentar diversas hipóteses o pesquisador deve analisar todo o material disponível, tanto aquele que apóia as suas hipóteses quanto os que não as apóiam. O planejamento, a coleta e a análise devem respeitar as regras da metodologia científica.

Inferência refere-se à operação pela qual se aceita uma proposição em virtude de sua relação com outras preposições já aceitas como verdadeiras. Se a descrição é uma primeira etapa de análise e a interpretação a última etapa, a inferência é um procedimento intermediário que permite a passagem entre uma e outra (BARDIN, 1979).

A interferência pode responder às seguintes perguntas:

1 O que leva a formular determinada preposição?

1 Quais são as causas ou antecedentes de uma mensagem?

1 Quais são os possíveis efeitos da mensagem?

Em outras palavras, a interferência pode ser resumida na formulação clássica: quem diz que, a quem, como e com que efeito?

A leitura do analista de conteúdo, segundo Bardin (1979), não é apenas uma leitura "ao pé da letra", mas um trabalho intelectual em nível mais aprofundado sobre a natureza psicológica, sociológica, histórica do evento estudado.

Pela sua natureza científica, a análise de conteúdo deve ser eficaz, rigorosa e precisa. Trata-se de compreender melhor um discurso, de aprofundar suas características e extrair os momentos mais importantes. Portanto, deve basear-se em teorias relevantes que sirvam de marco de explicação para as descobertas do pesquisador (RICHARDSON, 1999). 
De acordo com Bardin (1979), as fases da análise de conteúdo organizam-se cronologicamente em: pré-análise, análise do material, tratamento dos resultados, inferência e interpretação.

A pré-análise é a fase de organização, de operacionalização e sistematização das idéias, quando se elabora um esquema preciso de desenvolvimento do trabalho.

É uma etapa bastante flexível que permite a eliminação, substituição e introdução de novos elementos que contribuam para uma melhor explicação do fenômeno estudado. Um bom trabalho nessa etapa é uma garantia importante para a análise posterior. Para tanto, primeiramente se faz uma leitura superficial do material, onde se toma contato com o material, deixando-se impregnar pelo seu conteúdo.

Em seguida, buscou-se organizar o material, de tal forma que o mesmo pudesse responder a algumas normas de validade: exaustividade (que contempla todos os aspectos levantados no roteiro), representatividade (que contenha a representação do universo pretendido); homogeneidade (que obedeça a critérios precisos de escolha em termos de temas, técnicas e interlocutores); pertinência (os documentos analisados devem ser adequados ao objetivo do trabalho). Diante desta organização procura-se formular hipóteses, pressupostos e objetivos.

Em relação ao material qualitativo, devem ser estabelecidos pressupostos iniciais, os quais devem ser flexíveis para permitir hipóteses emergentes a partir de procedimentos exploratórios. Para isso, deve-se recolher material semelhante, essencial e rico na informação necessária.

A análise do material, segundo Bardin (1979), consiste essencialmente na operação de codificação, transformando os dados brutos em dados que consigam 
alcançar o núcleo de compreensão do texto. Trabalha-se nessa fase primeiro, com o recorte do texto em unidades que podem ser uma palavra, uma frase, um tema, um personagem, um acontecimento, tal como foi estabelecido na pré-análise (MINAYO, 2000). No presente estudo usamos frases ou fragmentos de frases, nesse processo de corte e recortes do conteúdo das falas das mulheres pesquisadas.

A base da metodologia da análise de conteúdo está na pergunta: Como analisar ou como tratar o material? Ou, como codificar? Segundo Richardson (1999) a codificação é um processo pelo qual os dados brutos são sistematicamente transformados e agrupados em unidades que permitem uma descrição exata das características relevantes do conteúdo. Assim, a codificação é uma transformação que segue regras especifícas para os dados de um texto.

Uma vez que os resultados brutos foram submetidos a operações de codificação e categorização, o conteúdo codificado deverá ser traduzido em informações relevantes que traduzam o significado daquele conteúdo para o objeto de investigação.

Após o tratamento dos dados, passa-se à fase de interpretação e inferência sobre os mesmos. Este momento é um período de forte trabalho intelectual, quando o pesquisador deverá apoiar-se no referencial teórico proposto para atingir a compreensão desejada e elaborar pressuposições ou hipóteses.

$\mathrm{Na}$ fase de interpretação dos dados do presente trabalho, apoiamo-nos em referenciais socioculturais, tomados da antropologia, para que pudéssemos apreender o cotidiano, à luz dos próprios sujeitos (mulheres histerectomizadas em decorrência de complicações no trabalho de parto e parto) e captar as relações que as mulheres estabelecem com questões relacionadas à qualidade de suas vidas. 


\section{CAPÍTULO IV: Resultados e Discussão}

\subsection{Caracterizando as mulheres estudadas}

Participaram deste estudo, dez mulheres histerectomizadas, cuja faixa etária esteve entre 16 e 32 anos, sendo cinco delas menores de 20 anos. Tratam-se de mulheres que engravidaram na adolescência.

Quanto ao estado civil, quatro mulheres eram casadas, duas viviam em união livre, três eram solteiras e uma era divorciada. As solteiras e duas das casadas residiam em casa própria, de seus pais. Uma residia em casa alugada, mas também junto de seus pais.

Em relação à renda familiar houve variação de dois até dez salários mínimos do México, sendo que o valor de um salário mínimo é de $\$ 1,200,00$ pesos mexicanos (\$1,200.00 P:M). Isso equivale a $\$ 110$ (dólares) ou a $\mathrm{R} \$ 330,00$ (reais).

No que diz respeito à escolaridade das dez mulheres entrevistadas, uma completou os seis primeiros anos do ensino básico (seis anos de estudo); duas tinham ensino secundário completo (9 anos de estudo), uma concluiu o ensino médio (12 anos de estudo) e 4 estavam cursando o $1^{\circ}$ semestre do ensino médio, no período da pesquisa. Duas mulheres terminaram o curso universitário. Cabe 
ressaltar que a maioria das mulheres entrevistadas referiu ter abandonado os estudos, sobretudo as adolescentes, em decorrência da gestação.

No que se refere à ocupação, quatro eram donas-de-casa, duas trabalhadoras autônomas, uma enfermeira, uma dentista e duas trabalhadoras no comércio, sendo elas vendedoras de lojas de roupas.

Uma delas residia na Cidade do México, a $30 \mathrm{Km}$ do local do estudo. As outras nove residiam na cidade de Nezahualcoyotl, Estado do México. Cinco delas residiam na periferia da cidade, em bairros pobres e perigosos, devido à alta incidência de alcoolismo, uso de drogas e vandalismo no local. Aí se destacam as faltas de pavimentação, de infra-estrutura, de saneamento básicas, assim como a coleta de lixo irregular e uma rede de transporte coletivo ineficaz. As outras quatro residiam em bairros cuja infra-estrutura sanitária é considerada adequada e próxima ao centro da cidade.

Quanto à forma de atendimento médico, apenas quatro mulheres referiram ter seguro social médico, embora não gostassem da atenção oferecida, razão pela qual procuraram o hospital onde deram à luz.

A vida sexual ativa das participantes do estudo iniciou-se entre os quatorze e os vinte anos de idade, e quando ocorreu a histerectomia, a paridade e o número de filhos vivos eram: cinco mulheres primíparas tinham filhos das seguintes idades: (E9 - 6 meses de idade); (E8 - 4 meses de idade); (E7 - 4 meses de idade); (E6 - 1 ano de idade); (E3 - 2 anos de idade). Uma delas era primípara e não tinha filho vivo (E10). Três eram secundíparas e as idades dos filhos eram as seguintes: (E5 - 8 meses e 8 anos de idade); (E1 - 1 ano e 5 meses e 10 anos de idade) e (E4 - 11 meses e 2 anos de idade). Uma mulher tinha três filhos (E2 - 1 ano, 10 anos e 13 anos de idade). 
Essas famílias eram constituídas, em geral, por seis pessoas, incluindo pai, mãe e filhos. Apenas uma das mulheres estudadas era chefe de família, trabalhando há nove anos em hospital.

Quanto ao tipo de parto realizado quando ocorreu a complicação, observouse que três foram partos naturais, por via vaginal, e sete foram partos operatórios.

As complicações que levaram à histerectomia, segundo os prontuários médicos foram: ruptura uterina (duas mulheres); atonia uterina no momento do parto (três mulheres); sepsis abdominal e infecção puerperal depois do parto (cinco mulheres). Segundo informações das próprias mulheres, três delas referiram ter apresentado pré-eclâmpsia, hipertensão induzida pela gravidez e anemia.

\subsection{Descrição pessoal de cada uma das mulheres entrevistadas}

\section{Entrevistada $n^{\circ} 1$}

Tem 32 anos de idade, religião católica. Quanto à escolaridade, completou os 6 primeiros anos do ensino fundamental (6 anos de estudo). Residia em Nezahualcoyotl, na periferia do Estado do México, com o marido e dois filhos, em casa própria, pequena. Pode ser classificada como pertencente à classe socioeconômica baixa, com renda mensal de três salários mínimos. Trabalhava em sua casa, confeccionando bolsas de material plástico, que seu marido vendia em outras cidades. Ele tinha 32 anos de idade, era vendedor, e não possuía seguro social médico. Relatou que iniciou sua vida sexual ativa aos 18 anos. Seus dois filhos foram de parto natural. Na ocasião da pesquisa tinham, respectivamente, 10 anos e 1 ano e 5 meses de idade. Realizou, na última gravidez, o controle pré-natal 
no centro de saúde, totalizando 6 consultas médicas. Foi então encaminhada ao Hospital Geral Dr. Gustavo Baz Prada, onde deu à luz. Segundo o prontuário médico, ocorreu ruptura uterina durante o parto, o que levou a um sangramento abundante e à necessidade da histerectomia (em $1^{\circ}$ de maio de 2002), para evitar um choque hipovolêmico. Ao falar sobre o processo vivenciado com a histerectomia, fez questão de reforçar que ama muito seus filhos, apesar de ter quase morrido no nascimento do segundo. Não sabe exatamente a razão da histerectomia. Pensa que seja por que sangrava muito durante o parto ou por que deixou passar muitos anos para engravidar novamente. Comentou que a cirurgia trouxe repercussões negativas à sua sexualidade, auto-estima e às suas relações sociais.

\section{Impressão do entrevistador}

O primeiro encontro aconteceu um ano e quatro meses após a cirurgia e durou 30 minutos. Ao receber-me, mostrou-se desconfiada, pela forma que me olhava, e não me deixou entrar em sua casa. Conversei com ela e expliquei-lhe que eu estava realizando uma investigação. Ela me disse que não queria saber nada sobre o hospital, e que estava ocupada, trabalhando. Consegui somente seus dados de identificação. O segundo encontro durou uma hora. Recebeu-me com maior confiança e permitiu-me entrar em sua casa. Ao recordar o processo da histerectomia, ela chorou e mostrou-se muito triste pelo ocorrido. Referiu que a cirurgia piorou seu relacionamento com o marido, que já não era satisfatório anteriormente.Tinha dificuldade em aceitar o afastamento dele. Chorou muito e referiu sentir-se deprimida, sem força, vazia, sem vontade para nada, abandonada e solitária, e que não via saída para sua situação. Disse que o marido a tratava com 
grosserias. Sentia que o desagradava e que tinha deixado de ser mulher para ele. No terceiro encontro que durou duas horas, relembrou episódios posteriores à cirurgia e voltou a falar dos mesmos problemas anteriormente mencionados. Pediume que conversasse com seu marido sobre a histerectomia e dissesse que isso não prejudicaria as relações sexuais. Tentei falar com ele, que se negou, argumentando falta de tempo. Revelou que, como seu marido afastou-se dela depois da cirurgia, tratava de resolver tudo sozinha como sempre fez em toda sua vida. Na tentativa de buscar soluções para seus problemas, procurava entendê-lo e assumir a responsabilidade de mudanças para que ele não se afastasse totalmente dela, e não se zangasse, chegando a agredi-las fisicamente. Como não sabia fazer outro tipo de trabalho e não contava com familiares próximos, ela dizia que, por seus filhos, suportava tudo isso. Sua maior preocupação era que seu marido deixasse de gostar dela e procurasse outras mulheres.

\section{Entrevistada $n^{\circ} 2$}

Tem 31 anos de idade, casada, religião católica. Quanto à escolaridade, tinha ensino médio completo (11 anos de estudo). Pode ser classificada como pertencente à classe socioeconômica baixa, com renda familiar de 4 salários mínimos. Era comerciante, e seu marido, com 35 anos de idade, operário qualificado. Residia em Nezahualcoyotl, com o marido e seus três filhos, em casa própria, pagando financiamento. Tinha seguro social médico, mas não gostava do atendimento. Relatou ter iniciado sua vida sexual ativa aos 20 anos. Teve um filho de parto natural e dois de parto operatório (um de 13 e um de 10 anos de idade). Realizou o controle pré-natal no centro de saúde, totalizando quatro consultas 
médicas. O último parto aconteceu no Hospital Geral Dr. Gustavo Baz Prada e, segundo o prontuário médico, teve complicação por sepsis abdominal, infecção puerperal e febre pós-cirurgia (em $1^{\circ}$ de outubro de 2002). Sobre o processo vivenciado com a histerectomia, ela acreditava que a cirurgia foi necessária porque deixaram passar muito tempo para realizar o parto, e por uma enfermidade grave a que o médico se referiu. Ao recordar a histerectomia chorou muito e manifestou tristeza, referindo que Ihe tiraram o útero e sentia-se mutilada por dentro. Comentou que a cirurgia trouxe repercussões negativas à sua sexualidade, à sua auto-estima e à sua relação com o marido e a família.

\section{Impressão do entrevistador}

O primeiro encontro aconteceu um ano após a cirurgia e durou uma hora. Não deixou que a entrevista fosse gravada e disse que primeiro tinha de me conhecer para saber quais eram as minhas intenções. Aceitei. Ela disse que as reais causas da histerectomia não Ihe foram esclarecidas pelo médico. Entretanto, argumentaram-Ihe que tinha uma infecção vaginal, transmitida possivelmente por seu marido. Referiu que ele mudou depois da cirurgia, e que isto afetava seu relacionamento conjugal. Enfatizou várias vezes que tinha medo de que o marido se aborrecesse com ela e a deixasse sozinha com os filhos, pois ele não queria estar com ela por muito tempo e a agredia, dizendo que não tinha culpa pelo que aconteceu com ela. A segunda e a terceira visitas duraram uma hora cada uma. Mostrou-se mais amável e deixou que a entrevista fosse gravada. Lembrou alguns episódios de sua vida como o de não poder contar com o marido, já que ele só se dedicava ao trabalho. Dizia não compreender porque lhe fizeram uma cesárea, se 
nada havia de errado com seu filho. Manifestou que não gostava de falar com ninguém sobre o que lhe aconteceu e que estava pensando em mudar de atitude com seu marido depois que ficou claro que ele não teve culpa pela infecção que ela adquiriu. Mostrou-se mais tranqüila ao reconhecer que seu marido é uma boa pessoa.

\section{Entrevistada $n^{\circ} 3$}

Tem 18 anos de idade, união livre, religião católica, cursando o $1^{\circ}$ semestre do ensino médio (9 anos de estudo). Residia em Nezahualcoyotl, em casa própria, dos sogros, compondo uma família de 8 pessoas, contando com ela. Pode ser classificada como pertencente à classe socioeconômica média, com renda mensal familiar de 8 salários mínimos. Era dona-de-casa e seu marido, de 23 anos, carpinteiro e trabalhava com seu pai. Relatou ter iniciado sua vida sexual ativa aos 14 anos. Tinha um filho de dois anos de idade, que nasceu de parto operatório. Não possuía seguro social médico. No pré-natal realizou somente 3 consultas médicas, no centro de saúde, e o parto aconteceu no Hospital Geral Dr. Gustavo Baz Prada. Segundo o prontuário médico, a histerectomia foi realizada devido a sepsis abdominal pós-cesárea (em 20 de junho de 2002). Ao falar da histerectomia, recordou-se de que no hospital não fora informada sobre a retirada do útero e que não poderia mais ter filhos. Referiu que teve uma infecção horrível na ferida operatória, febre, calafrios, sangramento e o médico lhe disse que se não a operassem, ela morreria. Isso lhe causou um grande desconcerto, pois não imaginou que precisasse de tal mutilação, sendo uma mulher tão jovem. Comentou que a cirurgia trouxe-Ihe repercussões negativas à imagem corporal, sexualidade, auto- 
estima, estilo de vida e incerteza sobre seu futuro e o de sua família, que acabara de formar.

\section{Impressão do entrevistador}

A primeira visita realizou-se um ano e quatro meses após a cirurgia, e durou uma hora. Percebi com medo, calada, com dificuldade para expressar-se comigo. Chorou muito quando falamos sobre a histerectomia e deixou claro que não foi informada das conseqüências que isso Ihe traria. Referiu ter amadurecido com a chegada de sua filha, pela responsabilidade por cuidá-la e educá-la. Esta situação afastou-a de seus convívios sociais e das amizades que tinha quando era solteira. A segunda visita durou uma hora e comentou das dificuldades que tinha com sua família e com a família de seu marido, porque eles não entendiam como ela se sentia após a histerectomia. Comentou que sua mãe disse-lhe para vigiar bem seu marido, uma vez que não podia mais lhe dar filhos. O terceiro encontro durou uma hora. Ela referiu que tem medo de que seu marido a deixe por outra mulher, e falou, chorando, sobre sua incerteza quanto ao futuro, temendo perder seu companheiro. Chamou-me a atenção a instabilidade emocional de ela ora chorando muito, ora agradecendo por estar viva e por poder seguir adiante.

\section{Entrevistada $n^{\circ} 4$}

Tem 30 anos de idade, divorciada, religião católica. Quanto à escolaridade, completou o curso universitário. Residia em Colônia Vicente Guerrero, México, D.F., a $30 \mathrm{Km}$ do local do estudo, com sua mãe e com seus filhos. Tinha casa própria, 
adquirida por financiamento social e possuía seguro social médico, apesar de não gostar da atenção recebida. Trabalhava como supervisora de enfermagem em um hospital. Relatou que o início de sua vida sexual ativa se deu aos 20 anos. Teve 2 filhos (11 anos e 2 anos de idade), um de parto natural e outro de parto operatório. $\mathrm{O}$ último parto aconteceu no Hospital Geral Dr. Gustavo Baz Prada. Segundo o prontuário, sua histerectomia foi realizada devido a uma atonia uterina, durante a cesárea (em 12 de janeiro de 2002). Realizou controle pré-natal no mesmo hospital, totalizando 7 consultas médicas. Recordando a histerectomia, falou com tristeza sobre o sangramento acentuado durante a cesárea, e que sentira muito frio, e medo em pensar que estava grave e que podia morrer. Comentou que a cirurgia trouxe-lhe repercussões negativas à sexualidade e à auto-estima.

\section{Impressão do pesquisador}

O primeiro encontro se deu um ano após a cirurgia e durou uma hora. Referiu que o primeiro problema que enfrentou após a cirurgia foi a separação de seu marido. Disse que desde que a operaram não voltou a ter relações sexuais com ele, e que se sentia "machucada" em pensar que tinha sido usada pelo marido durante anos, pois ele falou que tinha feito um favor em se casar com ela e que ela não merecia o amor dele, ainda mais agora que estava vazia. Relatou que ele não entendia que o útero não era importante nas relações sexuais, apesar de ele ser um grande filósofo. Referiu que já não chorava muito e não se sentia mutilada como nos primeiros oito meses após a cirurgia. Superou a depressão causada tanto pela cirurgia quanto pelo divórcio. A segunda e a terceira entrevistas duraram uma hora cada uma, mostrou-se mais tranqüila e referiu outras dificuldades que enfrentou, 
como a de não poder relacionar-se com outros parceiros, porque ao mencionar-lhes que não podia ter filhos eles se afastavam. Afirmou que vive para seus filhos e que parou de pensar se vai ficar sozinha ou arrumar alguém, afirmando que não quer mais relacionar-se com ninguém, para que não a "machuquem" novamente.

\section{Entrevistada $n^{\circ} 5$}

Tem 31 anos de idade, casada, religião católica. Quanto à escolaridade, possui ensino médio completo (11 anos de estudo). Residia em Nezahualcoyotl, em um bairro perigoso, com seu marido e seus filhos, em casa própria, pequena, ainda em construção. Era dona-de-casa, e seu marido, com 37 anos de idade, era torneiro. Pode ser classificada como pertencente à classe socioeconômica baixa, com renda mensal de 3 salários mínimos. Não tinha seguro social médico. Relatou ter iniciado sua vida sexual ativa aos 18 anos, e tinha 2 filhos ( 8 anos e 8 meses de idade). Realizou o pré-natal no centro de saúde, totalizando sete consultas médicas. Seu segundo parto se deu no Hospital Geral Dr. Gustavo Baz Prada, e ocorreram complicações por não ter havido descida fetal e o trabalho de parto ter durado 14 horas. Segundo o prontuário médico, foi realizada histerectomia por hipertensão induzida pela gravidez e sepsis abdominal. Recordou-se da histerectomia falando que tudo começou com a febre e a dor na ferida cirúrgica, depois da cesárea. O médico disse-lhe que tinha uma infecção muito grave e que se não fosse operada, poderia morrer ou ter câncer. Aos dois dias após a cesárea, foi feita a histerectomia, porém nunca Ihe informaram que retirando seu útero ela não poderia voltar a ter filhos, informaram apenas que Ihe salvaram a vida. Comentou que a cirurgia trouxeIhe repercussões negativas à sexualidade, à auto-estima e à imagem corporal. 


\section{Impressão do entrevistador}

A primeira visita se deu depois de cinco meses da cirurgia e durou uma hora. Ao iniciar a conversa, começou a chorar pela situação vivida, dizendo que sentia-se mutilada, inferior, vazia e assinalada pela sua família. Outra dificuldade que enfrentou foi seu marido dizer-Ihe que a castraram, fazendo-a sentir-se culpada pelo que aconteceu. Disse que após a cirurgia, engordou muito e que a cicatriz cirúrgica a deformou, e o marido não a via mais como a mesma pessoa que era antes. Na segunda visita voltou a chorar comentando esses mesmos problemas. Referiu que nem seus pais, nem seus sogros entendiam sua situação, e por isso, já não falava com eles. Sua mãe dizia que ela devia manter-se calada, obediente e cuidando de seu marido para que ele não a deixasse. Na terceira visita ela quase não chorou, mas comentou sobre a angústia da relação com seu companheiro que Ihe diz que ela não serve para mais nada. Falou que depois da cirurgia ela não queria estar com o companheiro, e que agora ele é que não queria estar com ela. Pediu para que alguém falasse com ele para fazê-lo entender que a cirurgia não tem nada a ver com as relações sexuais. Tinha medo de que ele a deixasse porque não sabia o que fazer para salvar essa relação. 


\section{Entrevistada $n^{\circ} 6$}

Tem 23 anos de idade, mãe solteira, religião católica. Quanto à escolaridade, completou o curso universitário. Residia em Nezahoalcoyotl, com seus pais e seu filho em casa própria. Pode ser classificada como pertencente à classe socioeconômica média, com renda mensal de 10 salários mínimos, de seus pais. Ela era dona-de-casa. Referiu que sua vida sexual ativa iniciou-se aos 17 anos. Tinha um filho de um ano de idade, que nasceu de parto natural. No pré-natal realizou quatro consultas médicas no centro de saúde e o parto aconteceu no Hospital Geral Dr. Gustavo Baz Prada. Conforme prontuário médico, a histerectomia foi realizada devido à atonia uterina e sangramento abundante no momento do parto (em 30 de agosto de 2003). Referiu que a retirada do útero foi a única maneira de deter a hemorragia e que nunca imaginou que fosse tão difícil ter um filho. Comentou que a cirurgia trouxe-lhe repercussões negativas à sua auto-estima, imagem corporal e incerteza quanto ao futuro.

\section{Impressão do Entrevistador}

A primeira visita se deu aos três meses depois da cirurgia e durou trinta minutos. A mãe de ela, recebeu-me sozinha e deu-me alguns dados, comentando que a filha estava ainda muito deprimida com a cirurgia. Não queria falar com ninguém e não saía do quarto, só ficava com seu bebê. A segunda visita, com confirmação prévia por telefone, três meses depois da primeira, durou uma hora. Recebeu-me com receio, assustada, com fáscies muito pálidas, e quando iniciamos a conversa começou a chorar muito, repetindo que a deixaram oca e não poderia ter 
filhos nunca mais. Doía-Ihe ainda a situação de ter perdido o útero e de ser mãe solteira. Tentei acalmá-la para que pudesse continuar falando comigo. Referiu que o problema mais difícil para ela foi aceitar esta situação, motivo pelo qual abandonou o serviço social que fazia. Deprimiu-se tanto que isolou-se da família e das outras pessoas. A terceira visita durou uma hora e meia. Ela estava um pouco mais tranqüila, já tinha começado a falar com seus pais, sobretudo com sua mãe. Referiu que a mãe a fez repensar a retomar o seu caminho. Iria continuar seu serviço social no mesmo lugar onde o tinha iniciado. Referiu também que pensava que não iria casar-se nunca e que nem poderia mais ser feliz por estar mutilada. Mas, por seu filho, devia seguir adiante.

\section{Entrevista $n^{\circ} 7$}

Tem 16 anos de idade, união livre, religião católica. Quanto à escolaridade tinha primeiro semestre do ensino médio (9 anos de estudo). Pode ser classificada como pertencente à classe econômica média, sendo que a renda mensal familiar, dela e de seu companheiro era de sete salários mínimos. Trabalhava como empregada em uma loja de comestíveis, e seu marido, de 19 anos de idade era motorista de transporte coletivo. Residia em Nezahualcoyotl, na casa de seus pais, junto com mais quatro irmãos. A casa de seus pais era própria, localizada a $15 \mathrm{Km}$ do local de estudo. Relatou que sua vida sexual ativa teve início aos 14 anos. Tinha um filho de quatro meses de idade, que nasceu de parto cesárea, por diagnóstico médico de hipertensão induzida pela gravidez e desproporção céfalo-pélvica. Realizou pré-natal no centro de saúde, totalizando cinco consultas médicas. O parto operatório aconteceu no Hospital Geral Dr. Gustavo Baz Prada. Depois de dois dias 
foi realizada a histerectomia devido à infecção puerperal, sepsis abdominal pós cesárea (em 02 de outrubro de 2003). Lembrava-se de ter sangrado muito depois da cesárea. O médico disse-lhe que tinha uma infecção muito forte e que a histerectomia havia salvado a sua vida, apesar de não poder mais ter filhos. Comentou que a cirurgia trouxe-Ihe transtornos à sexualidade, à auto-estima e à imagem corporal.

\section{Impressão do entrevistador}

A primeira visita foi realizada aos quatro meses após a cirurgia e durou uma hora. Relatou chorando o fato de que lhe tiraram o útero e de que não voltaria a ter filhos. Não entendia porque nunca lhe disseram nada no centro de saúde. Sua mãe Ihe falava que aos homens só interessava que as mulheres tivessem filhos. Por isso ela se sentia vazia, castrada, pois já não tinha nada a oferecer. Sentia-se culpada pelas recriminações de sua mãe sobre seu comportamento antes de ter idade para casar-se. Outra dificuldade foi que ela e seu companheiro tiveram que deixar de estudar e por isso não tinham um bom emprego e um bom salário. A segunda e a terceira visitas duraram uma hora cada uma. Mostrou-se mais tranqüila; sua mãe não estava presente. Sua principal angústia era que na cicatriz cirúrgica havia se formado um quelóide e ela sentia-se muito feia e preocupava-se em relação à opinião do companheiro. Tinha dúvidas também se ele continuaria com ela, pois sua mãe havia lhe dito que os motoristas são muito mulherengos. Tinha medo de que ele a deixasse por outra mulher, já que não podia mais ter filhos. Sabia que agora era responsável por cuidar e educar sua filha e esperava algum dia poder viver somente com ela e com seu marido. 


\section{Entrevistada $n^{\circ} 8$}

Tem 16 anos de idade, mãe solteira, religião católica.Quanto à escolaridade tinha o primeiro semestre do ensino médio (9 anos de estudo). Residia em Nezahualcoyotl, em casa própria, adquirida por sua mãe, por prestações ao governo. Vivia com ela, com sua filha e suas irmãs, e trabalhava como empregada em uma loja de roupas. A mãe era secretária em escritórios do governo. Pode ser classificada como pertencente à classe socioeconômica baixa, com renda familiar de quatro salários mínimos.

Relatou ter iniciado sua vida sexual ativa aos 14 anos. Tinha uma filha de quatro meses de idade, que nasceu de parto cesárea. Realizou o pré-natal no centro de saúde, totalizando três consultas médicas. O parto operatório aconteceu no Hospital Geral Dr. Gustavo Baz Prada, por desproporção céfalo-pélvica, hipertensão induzida pela gravidez e anemia de primeiro grau.

A histerectomia aconteceu por infecção puerperal e hipertensão induzida pela gravidez (em 20 de novembro de 2003). Lembrou que antes da histerectomia teve medo de morrer e sentia que delirava muito. Não foi informada por ninguém de que não poderia mais ter filhos e comentou que a cirurgia trouxe-lhe transtornos à sexualidade, auto-estima e imagem corporal.

\section{Impressão do entrevistador}

A primeira visita se deu aos quatro meses depois da cirurgia, durou uma hora e a mãe de ela estava presente porque havia ido ao hospital para certificar-se da legalidade de minha visita. Ao lembrar tudo que lhe aconteceu e tudo pelo que 
ainda estava passando, chorava muito. Mostrava-se tímida e insegura, olhando para sua mãe enquanto falava. Sua mãe a culpava pelo pai tê-las abandonado, mas ele já tinha saído de casa antes de ela engravidar. Comentou que a mãe reprovava, constantemente, sua atitude de rebeldia e o fato de ela ter permitido que a engravidassem e a abandonassem. O que mais lhe dava raiva era pensar que sua vida podia ser diferente, mas já que ela causou tudo isso, agora teria de agüentar. Outra dificuldade relatada por ela, é a de que com sua pouca idade não conseguiu encontrar um bom emprego. A segunda visita durou uma hora e, sua mãe não estava presente, chorou menos, mas mostrou-se triste. Referiu que a cicatriz cirúrgica Ihe deixava muito feia, não podendo usar trajes de banho, e, além disso, sentia-se pecadora e mutilada. Pensava que nunca mais poderia ser feliz, nem encontrar um parceiro, porque tinha toda a culpa pelo que Ihe aconteceu. Comentou que a mãe lhe disse que deveria apenas dedicar-se à sua filha e trabalhar, e que ela não tinha mais o direito de sair e divertir-se como antes. Na terceira entrevista, que durou uma hora, mostrou-se mais tranqüila, mas insegura para falar. Penso que isso aconteceu porque é muito jovem. Falou sobre a preocupação em não poder casar-se e ter mais filhos. Estava triste porque o pai de sua filha as abandonou sem nem mesmo conhecer a menina. Percebi a influência de sua mãe em relação ao que pensa sobre o papel da mulher que é mãe solteira. Seus preconceitos fizeram com que ela se sentisse pecadora.

\section{Entrevistada $n^{\circ} 9$}

Tem 20 anos de idade, casada, religião católica. Quanto à escolaridade, tinha ensino médio completo (11 anos de estudo). Residia em Nezahualcoyotl, com 
seu filho e seu marido, em casa própria, pagando-a ainda. Seu marido, de 26 anos de idade era carpinteiro qualificado. Pode ser classificada como pertencente à classe socioeconômica média, com renda mensal de sete salários mínimos. Relatou ter iniciado sua vida sexual ativa aos 16 anos, e tinha um filho de seis meses de idade, nascido de parto natural. Realizou, no pré-natal, quatro consultas médicas, no centro de saúde. O parto aconteceu no Hospital Geral Dr. Gustavo Baz Prada. Referiu que a histerectomia teve como causa atonia uterina e pré-eclâmpsia, com sangramento abundante e que ela chegou a perder a consciência (em 3 de dezembro de 2003). Ao relembrar a cirurgia, referiu que no início do trabalho de parto sentiu dores tão fortes que perdeu os sentidos. Após seu filho nascer, começou a sangrar muito, e o médico lhe disse que não havia outra forma de estancar o sangramento que não fosse a histerectomia. Comentou que isso Ihe salvou a vida, apesar de ter ficado castrada. Disse que a cirurgia trouxe transtornos à sua sexualidade, auto-estima e imagem corporal.

\section{Impressão do entrevistador}

O primeiro encontro se deu aos três meses após a cirurgia e durou uma hora. Ela chorou muito e referiu sentir-se triste por não poder mais ter filhos e que seu útero era o que tinha de mais importante. Como mulher, disse sentir-se vazia e que vivia na incerteza sobre tudo no futuro. Relatou que a histerectomia mudou seu corpo, dividindo seu abdome ao meio, além de ter engordado muito após a cirurgia.

Disse que se sentia como um fenômeno, gorda e marcada pela cicatriz. Na segunda visita, que durou 70 minutos, chorou muito, comentando que seu marido, apesar de ser bom, falava, brincando, que tinham dividido sua barriga em duas partes e parecia 
que ela havia sido marcada como se marcam os animais. Sentia ainda que sua relação com ele havia mudado, e que já não lhe interessava como mulher, principalmente pelo grande aumento no seu peso corporal. Referiu que o marido dizia que iria procurar filhos por outros lugares, e que não era para ela se assustar com isso, disse que não aceitava tudo pelo que havia passado e que sua família a "assinalara", fato que a fez afastar-se de todos.

\section{Entrevistada $n^{\circ} 10$}

Tem 17 anos de idade, mãe solteira, religião católica. Quanto à escolaridade, cursava o primeiro semestre do ensino médio (9 anos de estudo). Residia na periferia do município de Nezahualcoyotl, longe do local do estudo, em casa própria, semiconstruída, de seus pais. O bairro não era muito urbanizado, e tratava-se de um lugar perigoso pelas altas taxas de vandalismo, alcoolismo e uso de drogas. Trabalhava em uma loja de roupas e não possuía seguro social médico. Pode ser classificada como pertencente à classe socioeconômica baixa, com renda familiar de cinco salários mínimos. Relatou ter iniciado sua vida sexual ativa aos 15 anos. Teve um filho, de parto operatório, que morreu ao nascer. Realizou o pré-natal no centro de saúde, totalizando quatro consultas médicas. O parto aconteceu no Hospital Geral Dr. Gustavo Baz Prada. O diagnóstico, segundo o prontuário médico, foi de desproporção céfalo-pélvica, hipertensão induzida pela gravidez, anemia e baixo peso fetal. A histerectomia teve como causa ruptura uterina e sangramento abundante (em 20 de julho de 2003). Ela referiu lembrar-se de que o bebê não conseguia nascer e precisou ser feita uma cesárea, e também ouvia dizerem que ela estava muito grave, sangrando muito e que seria preciso retirar seu útero. A partir 
daí ela sentiu muito sono, dormiu e quando acordou, a cirurgia já havia terminado, mas ninguém lhe disse que o bebê estava morto. Comentou que a cirurgia lhe trouxe transtornos à sexualidade, à auto-estima, à imagem corporal e ao relacionamento social.

\section{Impressão do entrevistador}

O primeiro encontro se deu aos oito meses após a cirurgia e durou 30 minutos. Ela estava trabalhando e sua mãe é quem passou-me alguns dados, como o fato de que deixou de comer adequadamente, desde o início da gravidez e isso afetou muito seu estado de saúde. Na segunda visita, depois de um mês da primeira, com duração de uma hora, estava muito triste, desanimada, frustrada e chorou muito ao falar sobre a morte do filho. Disse que o mais difícil para ela foi enfrentar os pais quando se deram conta de que ela estava grávida, e o fato de ter perdido o filho é uma situação que ainda não havia conseguido superar. Falou ainda que deixara de ser "uma menina mimada para ser uma mulher mutilada". Comentou que seus pais a advertiam pelo fato de o noivo não ser um moço responsável, mas ela não os ouviu e continuou com ele. Disse que os pais quase a mandaram embora de casa, e que ela só teve a perder com essa situação. Disse também pensar que devia ser sempre uma boa filha e obedecer os pais, pois quando isso não acontece, Deus castiga. Relatou, chorando muito, que estando mutilada por dentro, não poderia mais ter filhos, e sentia-se uma pecadora. Referiu tristeza também por ter perdido o ano de estudo, e que agora seus pais não a deixavam voltar a estudar, e que ela deveria somente trabalhar. A terceira visita durou uma hora. Chorando, falou que não via saída para seus problemas, não conseguia encontrar um caminho 
melhor para seguir, e que pensava no futuro, quando não poderia casar-se. Pensava em como seria sua vida depois de dez anos, se agora já estava oca por dentro e com medo de relacionar-se com outros homens. Comentou sobre a cicatriz cirúrgica que a fazia sentir-se mal consigo mesma, e ainda que seus pais a recriminavam constantemente, recordando o passado e culpando-a pela morte do filho. Referiu também que só saía de casa para trabalhar. Dizia que como já não tinha as "regras" e o útero, e isso é que lhe fazia mulher, ela já não podia mais fazer muitas coisas.

\subsection{A histerectomia por complicação do parto na vida das mulheres} estudadas

De acordo com a análise dos depoimentos, das entrevistas realizadas com as mulheres que se submeteram a histerectomia, em decorrência a complicações do parto, foi possível identificar unidades temáticas que convergiram para três temas:

1- Percepção dos motivos da histerectomia.

2- A perda como motivo de sofrimento.

3- Mudanças no corpo físico e no corpo social.

\subsubsection{Percepção dos motivos da histerectomia}

As explicações dos problemas de saúde centradas no paciente, segundo Helman (1994), são importantes, pois determinam se os indivíduos arcam com a responsabilidade de sua saúde ou vêem a origem e cura das doenças como algo além de seu controle. Isto porque, segundo o autor, médicos e pacientes vêem os problemas de saúde de maneiras muito diferentes, mesmo quando possuem o 
mesmo background cultural. As suas expectativas estão baseadas em premissas diferentes e empregam diferentes sistemas de prova e avaliação sobre a sua condição.

O fato de as mulheres estudadas falarem sobre a situação de serem histerectomizadas fez com que trouxessem à memória os motivos que as levaram a essa condição. Assim, deixaram em evidência que as reais causas para serem submetidas à mutilação não foram esclarecidas de forma a satisfazê-las, pois quando tomaram ciência dessa necessidade, o fato já havia acontecido.

“...só sei que tinha muita febre e delirava, que nem me dei conta em que momento, nem em que hora me operaram...”(E2)

De acordo com a opinião de cada uma delas, as causas que as levaram à cirurgia foram: temperatura alta ou infecção, sangramento vaginal, anemia, distócias, risco de adquirir câncer e necessidade de salvar suas vidas.

Ao reportarem sobre a percepção da febre alta ou infecção como uma das causas que as levaram a se submeteram à histerectomia, elas situam tais complicações dentro de um espaço temporal, ou seja após o procedimento parto cirúrgico - a cesárea:

“...pela febre que me deu e não baixava depois da cesárea ...”(E5)

“...depois da cesárea tive muita temperatura e não baixava, depois de um dia, voltaram a me operar porque me disse o doutor que tinha uma infecção muito forte.”(E7) 
Da mesma forma, as mulheres buscaram confirmar a assertiva de suas percepções sobre a infecção como a causa que as levaram à histerectomia quando descrevem o estado em que se encontravam.

“...tive uma infecção horrível na ferida... me deu febre, calafrio e desânimo.”(E3)“... por causa da temperatura tão alta que tive e senti que delirava..."(E8)

Apesar do sangramento estar presente na explicação sobre as razões que levaram algumas mulheres a se submeterem à histerectomia, este indicador, como outros, não é apresentado por elas como uma situação percebida objetivamente, pois foi através da informação de outros que elas tomaram conhecimento sobre a situação grave por que passaram:

"foi horrível que me disseram que estava sangrando muito. Para que parasse o sangramento tiveram que me operar... para tirar a matriz, porque era a única maneira de deter a hemorragia..."(E3)

$\mathrm{Na}$ tentativa de compreender e incorporar no seu universo simbólico as razões que levaram os profissionais que lhes assistiam a retirarem o seu útero, elas fazem um esforço deliberado para rememorar cada instante da situação vivenciada, de forma a fazer-se acreditar que um fato crítico, como a presença de hemorragia ou de infecção, esteve presente como algumas delas relataram:

“...nasceu minha filha e comecei a sangrar muito, é o que eu escutava... o mesmo médico me disse que não havia forma de parar o sangue e tiveram que me operar...”(E9) 
“...durante o parto, o médico que me atendeu dizia que sangrava muito, depois eu dormi e quando despertei já me haviam operado...."(E1)

“...porque sangrei muito no momento da cesárea, eu sentia que estava morrendo."(E4)

Da mesma forma, algumas mulheres identificaram ou outros as fizeram crer na existência de fragilidade em seus corpos, tornando-os vulneráveis a complicações. A presença de anemia foi uma das condições corporais de susceptibilidade às complicações identificadas pelas mulheres:

“...me disseram que estava muito grave porque sangrei muito $e$ teria uma anemia...”(E10)

“...sei que tinha um pouco de anemia.”(E2)

“...escutei que disse o médico que teria um pouco de anemia."(E8)

A distócia, no momento do parto, foi outra condição as levou à histerectomia, conforme relatado por algumas mulheres:

“...só me disseram comigo, tive distócia das partes moles.."(E4)

"...como eu era estreita, o médico disse que me realizaria uma cesárea...”(E7)

"...disse o médico que era muito estreita, por isso realizaram a cesárea."(E8)

A necessidade de realização da histerectomía como medida preventiva de um dano maior, como a aquisição de câncer, foi a explicação dada para algumas mulheres sobre a necessidade daquela intervenção. 
“...não é ruim, porque não vou correr o risco de ter câncer..."(E2)

“... me explicaram as conseqüências de não fazê-lo incluindo a possibilidade de ter câncer "(E5)

Para algumas mulheres, apesar de deixarem em evidência as conseqüências emocionais e sociais nas suas vidas, elas assumem que a realização da histerectomia foi a possibilidade de salvar suas vidas, mesmo não sabendo porque a indicação foi feita.

“...só dou graças a Deus que estou viva..”(E1)

“...”...me disseram que estive muito grave... Por isso tiveram que tirar a matriz para salvar-me.”(E10)

Ao configurarem no seu universo simbólico que a histerectomia salvou suas vidas, as mulheres deixaram em evidência quais foram os atores sociais que auxiliaram na construção deste processo de significação. Assim, as mulheres identificaram o médico como o elemento chave para a construção da rede de motivos para se submeterem à histerectomia:

“...O doutor me disse que o meu útero já estava muito gasto por uma enfermidade mortal e me voltaram a operar para salvar minha vida .”(E2)

...O médico me disse que tinha que me operar outra vez, pois tinha uma infecção e se não me operasse eu poderia morrer”.(E3) 
$\mathrm{Na}$ tentativa de delimitar o espaço simbólico envolvido no processo de indicação da histerectomia, algumas mulheres questionaram se não houve equívoco por parte dos médicos, em relação a seus casos, em particular.

“...por isso penso se não haviam equivocado comigo.”(E7)

“... se tudo ia bem até agora, tenho a dúvida porque a $\operatorname{mim} . . . ”(E 1)$

Percebe-se, portanto, que mesmo tendo já passado algum tempo, ainda não aceitavam este fato, como parte de sua realidade. 


\subsubsection{A perda como motivo de sofrimento}

No presente estudo, as mulheres estudadas ao falarem sobre a condição em que se encontravam, apresentaram um conjunto de manifestações que expressa como tem sido o cotidiano de suas vidas após terem sido submetidas a histerectomia. Apresentaram uma série de associações simbólicas, revelando um padrão de anormalidade que as coloca em condição de vítima de sua própria sorte.

Assim, mostraram-se incansáveis ao afirmar que sofrem porque, a partir da histerectomia se tornaram portadoras de um corpo vazio, mutilado, fazendo-as sentir como sendo seres inferiores, tendo que conviver com o desajuste social e com um futuro incerto.

\subsubsection{A experiência de um corpo vazio: o caos}

O corpo humano, para os membros de qualquer sociedade, é mais do que um simples organismo físico que oscila entre a saúde e a doença. O corpo é também o foco de um conjunto de crenças sobre seu significado social e psicológico, sua estrutura e funcionamento (HELMAN,1994)

Cada sociedade elege um certo número de atributos que configuram o que o ser humano deve ser, tanto do ponto de vista intelectual ou moral, quanto do ponto de vista físico. Para Rodrigues (1984), esta constelação de atributos é, em certa medida, a mesma para todos os membros de uma sociedade, embora esta possa apresentar ligeiras diferenças segundo os diferentes grupos, classes ou categorias que a sociedade apresenta. Portanto, é a sociedade e cada fragmento social, quem 
decide o ideal intelectual, afetivo, moral ou físico que deve implementar nos indivíduos, e isto se dá através do processo de socialização de homens e mulheres.

Para Rodrigues (1984), ao realizar este trabalho de construção de significados e atribuições ao ser humano, a cultura dita normas em relação ao corpo, por meio das quais o indivíduo tenderá ou mesmo obrigar-se-á a se conformar até que tais comportamentos (aqueles tidos como normais) se apresentem perante a sociedade como naturais.

No presente estudo, a experiência da histerectomia foi interpretada pelas mulheres estudadas a partir dos significados transmitidos a elas e incorporados de acordo com os padrões culturais estabelecidos a que foram expostas sobre a que se presta (ou uso de) aquela determinada parte do corpo - o útero. Nesse sentido, a experiência da histerectomia em decorrência da complicação do parto é vivida e permeada por sofrimento de diversas ordens.

Sofrimento, primeiro porque trata da constatação da falta de completude de seu corpo biológico.

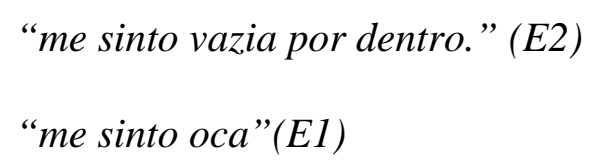

A perda da inteireza corporal traz conseqüências para o seu corpo, reduzindo-o à função social - a maternidade.

E depois, as mulheres manifestaram o quão doloroso tem sido para elas o ajustamento daquele corpo social à nova condição, na tentativa de atingir a superação. 
"e que isso me faz sentir menos, quiçá até feia, vazia, sim matriz...(E7)

A percepção de seus corpos, pelas mulheres deste estudo, revelou a forma como se processa e se estabelece a organização da sociedade e o modo de relação dos corpos com as coisas, como evidenciado nos seguintes depoimentos:

“...nunca lhe gostei...ele nunca gostou de mim e agora menos ainda que estou vazia, impossibilitada de ser mãe..(E4) “não poderei ser feliz, me sinto mutilada”(E3)

"Significou como perder parte de meu corpo, de mim, de ser como mulher...”(E5)

Revelaram as mulheres que, conforme a sociedade está estruturada, elas pertencem a um determinado grupo social, com atributos e funções definidas - o grupo representado pelo gênero feminino.

As sociedades humanas dividem suas populações em duas categorias sociais: "masculina" e "feminina". A cada uma delas, é ditada uma série de pressupostos, retirados da cultura em que ocorre, sobre os diferentes atributos, crenças e comportamentos característicos dos indivíduos incluídos dentro daquela categoria (Helman,1944). Para as mulheres estudadas, o principal atributo que as define dentro da categoria gênero feminino relaciona-se à maternidade:

“ minha mãe diz que os homens, só lhes interessa que a mulher tenha filhos.”(E7) 
A divisão binária da humanidade em dois gêneros revela-se como um fenômeno complexo e com muitas variações, as quais se apresentam segundo a maneira com que os comportamentos "masculino" e "feminino" são definidos nos diferentes grupos culturais (HELMAN, 1994).

É razoável afirmar que, tanto as influências biológicas quanto as ambientais participam da definição de gênero de qualquer indivíduo. Em todas as sociedades, homens e mulheres possuem formas corporais e ciclos fisiológicos distintos. As mulheres menstruam dão à luz e amamentam; os homens não. Estes são significados culturais dados aos eventos fisiológicos, que por sua vez, influenciam o comportamento das pessoas ou mesmo o sistema social, político e econômico da sociedade (HELMAN,1994)

Em todas as sociedades, a divisão do mundo social em categorias masculina e feminina significa que são socializados de maneira muito diferentes. Eles são educados para ter expectativas diferentes em relação à vida, para desenvolver a emoção e o intelecto de formas distintas, além de estarem sujeitos a diferentes normas de vestuário e comportamento na vida diária. Seja qual for a contribuição da biologia para o comportamento humano, é evidente que a cultura também contribui com um conjunto de diretrizes explícitas e implícitas, que são adquiridas na primeira infância, as quais ditam ao indivíduo sua maneira de perceber, pensar, sentir e agir como membro masculino ou feminino daquela sociedade (HELMAN,1994).

Reportando aos dados do presente estudo, as mulheres têm consciência de que a retirada do útero as colocou em uma outra posição social perante o seu próprio grupo - o grupo das mulheres - cujas conseqüências evidenciam-se nas relações com o seu mundo social. E por isso sofrem. 
“...já não sou mulher completa, eu não posso ter filhos, creio que isto pode trazer-me problemas com meu marido.”(E3)

O fato de ser histerectomizada e conseqüentemente não mais poder ter filhos coloca-as em uma posição de desvantagem perante o seu grupo e nas relações que estabelecem com o gênero masculino.

Crescemos em bases culturais, familiares e sociais as quais estabelecem uma imagem feminina marcada pela crença de que a mulher vive na sociedade e no mundo para ser mãe, para procriar e parir. O culto de que o ser mãe é o presente mais formoso e maravilhoso da vida, da natureza feminina, faz com que as mulheres tomem tais crenças como seu arcabouço de sustentação. E quando tal presente lhes é negado, toda uma vida se desmorona.

$$
\begin{aligned}
& \text { “..me sinto muito feia pelo simples fato de não poder ter } \\
& \text { filhos...”(E8) } \\
& \text { “...depois senti que sem a matriz, não valho nada...”(E2) }
\end{aligned}
$$

No entanto, o valor de uma mulher não se encontra nem em sua matriz, nem em seus ovários, muito menos no número de vidas que consciente ou inconscientemente traz para este mundo (HIERRO,1996).

Este valor se encontra em sua mente, em seu coração, em seu espírito, encontra-se em sua fortaleza, em sua capacidade de aprendizagem, em seu desenvolvimento, na busca por evolução como ser humano. O valor do ser humano está na sua constante inovação, em sua transcendência, em sua capacidade de transformar o seu ambiente (HIERRO,1996). A forma encontrada pelas mulheres estudadas para anunciarem o quanto a sociedade lhes destitui valor e para 
responderem ao seu novo corpo social é sentindo-se frustrada, deprimida e desvalorizada.

O ser humano pode perceber-se a si mesmo, ter concepções de si, comunicar-se consigo mesmo, e assim, tornar-se objeto de sua própria ação. As mulheres revelaram que o fato de terem sido histerectomizadas fez com que convivessem com sentimentos de frustração, angústia, depressão, tristeza, porque não podiam cumprir com a função reprodutora. Este processo representa para elas, um conjunto de significados que cada uma delas evidencia de acordo com a realidade de seu universo simbólico em que se desenvolve (BLUMER,1969).

“... desde que me ocorreu isto me sinto degradada...(E1)

“...depois disso (cirurgia) me fez sentir mal comigo mesma..."(E3)

“...me sentia só, deprimida e feia...”(E4)

“..pois me senti muito deprimida ao saber que não podia voltar a ser mãe...”(E6)

Em sociedades menores, particularmente, a mulher estéril é freqüentemente marginalizada, vista como uma pessoa frustrada e socialmente incompleta. Na maior parte das sociedades tradicionais, a culpa deste fato recai, normalmente sobre a mulher (HELMAN,1994).

Portanto, a partir da maternidade, a mulher obtém um status social de prestígio, dado que a maternidade é altamente valorizada na sociedade em geral e na mexicana, em especial, o que demonstra traços de uma cultura machista, pois paira a crença de que fazer filhos, para o homem é sinônimo de potência, de bom reprodutor, sobretudo quando consegue gerar meninos (HIERRO,1996). 
“...pois meu esposo, disse que como não vou mais ter filhos, tentará conseguir filhos de outro lado, outra forma...”(E9)

“...e agora com a operação se tornou mais agressivo comigo ...

e se vou buscar uma mulher completa, não como a que ele tem...”(E1)

\subsubsection{Percebendo-se inferiorizada}

A qualidade de vida pessoal é influenciada pela forma como cada pessoa valoriza-se e percebe-se no seu mundo social. Esta valoração que cada indivíduo faz de si mesmo é o que se conhece como auto-estima.(SHEEMAN,2000).

Quando a valoração que fazemos de nós mesmos é benéfica para nossa vida, pode-se dizer que temos uma auto-estima positiva, enquanto que, se for prejudicial, achamos-nos ante uma auto-estima negativa (SHEEMAN,2000)

A auto-estima positiva contribui para um conjunto de efeitos benéficos para nossa saúde e qualidade de vida, que se manifesta no desenvolvimento de uma personalidade mais plena e uma percepção mais satisfatória da vida. Aumenta a nossa capacidade de confrontar e superar as dificuldades pessoais, fomenta a capacidade de assumir compromissos e, portanto, de sermos mais criativos e produtivos.

Ao aumentar a confiança em nossas próprias capacidades pessoais, fundamenta-se e solidifica-se a nossa autonomia pessoal. Ao aumentar a confiança em nós mesmos, somos mais capazes de fixar nossas próprias metas, permitindonos estabelecer relações sociais mais igualitárias e satisfatórias. Quando a auto- 
estima mostra-se negativa, nossa saúde se ressente porque falta-nos confiança em nós mesmos para abordar as sucessivas provocações que a vida nos apresenta, e isto faz com que a qualidade de nossas vidas não seja tão boa quanto pudesse ser (SHEEMAN,2000).

As mulheres do presente estudo, sem exceção, fazem questão de salientar que o status social de cada uma delas sinaliza por um nivelamento que as inferioriza na escala social e em seu contexto social.

“desde que me ocorreu isto me sinto degradada..." me sinto inconformada, menos, algo de mim se acabou.”(E1\} “...me sinto muito mal...me sinto menos quando ele me diz que nem mulher sou mais”(E5) “...ao recordar que não tenho a matriz me faz sentir menor, triste e choro por tudo...”(E7)

Para as mulheres estudadas é no enfrentamento do seu contexto social, no seu cotidiano que a sua posição social vai se definindo como uma pessoa inferior, cuja identidade é permeada por um universo simbólico que favorece a vivência de uma baixa qualidade de vida.

“...diante desta situação que me encontro, sinto que todos têm pena de mim”.(E8)

“meu pai me visitou no hospital e lhe doía, a minha família se lastimava..”(E6)

“...então me sinto marcada, me olhavam com pena, com lástima pelo que me passou e pelo que estou hoje.”(E6) 
No conjunto de percepção sobre as repercussões da histerectomia em suas vidas, as mulheres estudadas evidenciam movimentos reflexivos sobre o papel de sua própria participação na configuração dessa posição e hierarquia que ocupam no seu contexto social. Neste processo de reflexão, muitas delas abandonam o papel de vítima para assumir o de ré. Sentindo-se, portanto, culpadas pelo ocorrido:

$$
\begin{aligned}
& \text { “meu esposo me olhava com desprezo fazendo-me sentir } \\
& \text { culpada...”(E4) } \\
& \text { “me faz sentir culpada, diz que perdi a estética...”(E5) } \\
& \text { “...me sinto muito culpada por tudo que me passa...”(E10) }
\end{aligned}
$$

Ao se colocarem como culpadas e condenadas pela situação da perda do útero, deixam, mesmo que de forma velada, transparecer que o surgimento de tais sentimentos fundamenta-se em padrões morais para o comportamento sexual do gênero feminino:

$$
\begin{aligned}
& \text { “...me senti pecadora, má filha porque meus pais me disseram } \\
& \text { que as coisas não saíam bem se não me casasse antes de ser } \\
& \text { mãe.”(E10) }
\end{aligned}
$$

A maneira tão enfática com que as mulheres se autoclassificam como culpadas pela situação de terem sido submetidas à histerectomia, mesmo não apresentando justificativas por tal nomeação, parece transparecer que elas incorporaram aquilo que Bourdieu (2003) identificou como habitus. O habitus, para o autor, é um conhecimento adquirido que indica a posição incorporada, quase postural de um agente em ação. Ou seja, permite-nos apreender que este sentimento de culpa expressado pelas mulheres revela a noção que elas têm para 
referir o funcionamento sistemático de seus corpos socializados e que, quando fogem à regra, o sistema de controle social se faz presente.

E como esclarece Geertz (1989), o ser humano é o animal que mais depende de mecanismos de controle, extragenéticos, de programas culturais para ordenar seu comportamento.

\subsubsection{Convivendo com desajuste social e conjugal}

O processo de adoecer é um processo social que envolve outras pessoas, além do próprio indivíduo doente. Tal processo envolve experiências subjetivas de mudanças físicas ou emocionais, como também a confirmação de tais mudanças por parte de outras pessoas (HELMAN, 1994).

Nos depoimentos das mulheres estudadas fica evidente que, apesar da recuperação do corpo físico, do seu pleno estado de saúde física, elas fornecem, em seus repertórios simbólicos, elementos sobre a experiência de ser histerectomizada, que as faz sentirem-se como seres doentes. Qualificam-se a si próprias como portadoras de uma doença social de difícil solução - convivem com problemas de desajuste social e marital.

“... a cada dia que passa meu esposo se afasta mais de mim....”

“...mas não conto com o apoio de meu marido...e não me faz conta, sinto que me tem machuca..."E2 
Ao reconstruírem tal universo simbólico, revelam o quanto os padrões culturais exerceram poder fundamental na instituição dessa categoria de sofrimento humano.

A cultura não é somente um código, nem um repertório comum de respostas a problemas recorrentes, é um conjunto compartilhado de esquemas fundamentais, previamente assimilados, a partir dos quais se articula uma infinidade de esquemas particulares, diretamente aplicados a situações também particulares (BOURDIEU, 2003).

$\mathrm{Na}$ construção do universo simbólico sobre as repercussões da histerectomia em suas vidas, as mulheres estudadas destacam além do homem/ parceiro sexual, a mãe como um elemento de fundamental importância para a manutenção do simbolismo que cerca os assuntos ligados à reprodução e sexualidade:

“... minha mãe me disse que os homens só interessam pela mulher que pode ter filhos...” (E7)

“... como minha mãe me disse que uma mulher vale por ter filhos...” (E3)

Diante da situação em que vivem as mulheres estudadas, o desajuste conjugal e a instabilidade conjugal foram situações configuradas dentro de seus espaços de vida que as fazem sofrer e as colocam em uma posição inferiorizada perante as competências maritais.

Historicamente, as relações de poder têm favorecido aos homens quando os mesmos assumem a posição de mando sobre as mulheres; quando a mesma sociedade concede este poder aos homens, pela diferenciação sexual e pela 
construção social que se faz sobre o gênero masculino. A caracterização da vida conjugal no México ou seja, no matrimônio, é considerada união legal de um homem com uma mulher quando é feita perante a igreja, perante as leis do estado (matrimônio civil).

Este matrimônio cristão, digamos católicos, é o que predomina em nosso país. Este modelo, na prática concreta, vê-se acompanhado de outros ideais de boa esposa e bom marido que não se originam totalmente nos princípios formais do cristianismo, pois tais ideais se associam e se aderem ao imaginário social dos jovens que pretendem casar-se ou que já se casaram. Tem-se então, formada uma imagem de boa esposa e de bom marido dentro do matrimônio tradicional vigente.

O marido bom identifica-se como: aquele que tem capacidade de prover os recursos econômicos, os bens necessários e possibilidades suficientes para cumprir as necessidades da mulher e de seus filhos (alimento, casa, vestimenta, educação e lazer). Portanto, no imaginário da noiva e sua família encontra-se muito arraigada a preocupação de encontrar a pessoa que pode satisfazer isto. O jovem e sua família também estão atentos para cumprir com isto e encontrar emprego ou formas de conseguir recursos.

Pede-se, em geral, que o marido seja um protetor da família, e que o faça com palavras e com exemplos, sobretudo diante de seus filhos. A discrição, a comedida frente a isto e certos temas sexuais, sejam um valor muito cuidado. Isto é esperado, sobretudo nas famílias fiéis aos princípios cristãos.

É considerada boa esposa aquela que tem capacidade para ser mãe, para conservar a sobrevivência dos filhos e que se dedique a eles desde o nascimento, em relação ao cuidado de sua saúde, higiene e de toda a educação. 
O depoimento das mulheres estudadas possibilita a apreensão deste ideário, especialmente quando elas se desclassificam como esposa e revelam que a sociedade dita regras para tais distorções. Nos seus universos simbólicos é configurado que, à medida que os seus corpos biológicos não respondem às funções sociais (gerar filhos) autoriza-se o parceiro a procurar outros corpos autorizados (para gerar filhos) através de relacionamentos extraconjugais Os seguintes depoimentos exemplificam tais concepções:

“... meu esposo me disse que como não vou voltar a ter filhos, terá que conseguir filhos de outra forma...” (E9)

“.. pois quando contei a ele o que aconteceu e que não mais podia ter filhos ele me deixou...” (E4)

No entanto, a forma como é configurado o ideário de boa esposa não deixa espaço para transgressões, pois é exigida da mulher uma maior transparência na sua conduta no terreno sexual, quer seja de caráter público ou privado, dentro da qual figura a fidelidade que deverá ser mantida a qualquer custo.

“... isso me dói, tenho que aceitar....”(E9)

A imagem cultural das mulheres mexicanas é feita para servir ao homem, com resignação, submissão e obediência; projeta uma imagem limitada, promovida por uma ideologia patriarcal, que com seus sistemas de valores, crenças e atitudes fomenta e privilegia o poder do homem sobre a mulher;

“... minha mãe disse que tenho que vigiar bem meu marido porque não posso mais ter filho...” (E3). 
A partir de atributos socialmente definidos às mulheres, os seus espaços de interação são reduzidos e elas ficam limitadas às suas possibilidades de desenvolvimento, conformando suas subjetividades, de tal maneira que todos seus desejos, necessidades, interesses e fantasias confluam para a maternidade.

“... e me disse que as outras mulheres estão melhores do que eu, mesmo aquelas mulheres da rua, porque elas sim são verdadeiras fêmeas, quando ele me diz isso acredito que morro por dentro..."(E1) “... porém não conto com o apoio de marido ...e ele não liga para mim, sinto que ele tem pena de mim...”(E2)

A definição social do corpo feminino e do ser feminino como espaço para a reprodução separa, por sua vez, a procriação do prazer sexual.

“me sinto humilhada, pisoteada, pois ele só quer satisfazer a ele mesmo e diz que eu já não sinto o mesmo...(E1).

“... quando meu esposo me recorda que me sacaram a matriz $e$ que ele já não sente o mesmo ao estar comigo, me ponho a chorar. “(E5).

Tais elementos simbólicos, expressos pelas mulheres, explicam o que Geertz (1989), traz quando refere que a cultura não deve ser vista somente como um complexo de padrões concretos de comportamento (costumes, tradições, hábitos), mas como um conjunto de mecanismos de controle para governar o comportamento. 
No contexto mexicano, a influência ideológica da igreja católica contribui para a construção de estereótipos, tanto que condena o erotismo feminino e estimula a sexualidade reprodutiva, exclusivamente, contribuindo assim, na conformação de um entorno de repressão sexual.

Por outro lado, as desigualdades de gênero na relação de casais manifestam-se também nos graus de autonomia ou dependência das mulheres ao acesso e controle do próprio corpo, de sua sexualidade, da procriação e saúde, e de sua dependência econômica ou vulnerabilidade frente à violência ou à estabilidade marital, assim como no exercício da maternidade como um espaço de poder e controle (ARREDONDO, 1997).

O poder que se institui ao homem prejudica a liberdade da mulher quando se empenham em decidir por ela, tanto economicamente como socialmente. É o mesmo que dizer que o domínio do homem sobre a mulher vai além dos sentimentos maritais, é mais de poder e controle.

$$
\begin{aligned}
& \text { “me assusta o fato de cair-me só, não sei fazer nada para } \\
& \text { sobreviver se ele me deixar.” (E5). }
\end{aligned}
$$

O controle social é tão forte sobre as questões relativas à maternidade a ponto de configurar que a família somente existe socialmente quando o casal tem filhos, revelando que os laços conjugais somente se solidificam com a chegada dos filhos.

“... tem-se a crença de que uma mulher somente é boa quando pode dar muitos filhos... e eu não posso mais. ”(E5) “... e ele me disse que eu não ia funcionar como mulher posto que me haviam castrado... que ele queria viver com uma 
verdadeira mulher e não com uma que já não serve, porque eu estava mutilada."(E4)

Por conta disso, não é difícil entender porque o corpo e a sexualidade constituem-se em lugar de interdição, não por conta da concepção de um corpo "natural", mas sim, por conta da construção dos sistemas de valores, da cultura e do discurso que os sustentam (FOUCAULT, 1994).

\subsubsection{Tendo um futuro incerto}

A vida cotidiana das mulheres estudadas, conforme seus relatos, revela uma realidade já objetivada, ou seja, construída por uma ordem sobre como conviver com um corpo biológico mutilado, carregado de significações negativas, que as faz sentir como sendo seres inferiores e conviver com desajustes sociais e conjugais. No entanto, sabemos que tal ordem foi designada antes mesmo que cada uma das mulheres tivesse passado pela histerectomia, uma vez que, o que se espera dos indivíduos que convivem em determinadas sociedades relaciona-se às determinações socioculturais.

“...agora tenho dúvidas se o meu esposo continuará comigo até

$$
\text { o final”. (E3) }
$$

Diante de tais designações, que conservam um forte caráter de significação, as mulheres estudadas, ao falarem de suas vivências, mostraram que estas já se tornaram rotinas em seus acervos de conhecimento sobre o seu cotidiano como 
mulheres histerectomizadas. A consciência desta ordenação social, que carrega traços de grande sofrimento, faz com que as mulheres temam os seus futuros.

"Vivo na incerteza de como será o meu futuro" (E1)

“... tenho dúvidas de como será minha vida mais para frente

(E3)”.

$\mathrm{Na}$ cultura mexicana as mulheres, ainda são muito reprimidas, sobretudo nas zonas semiurbanas e rurais; não têm liberdade de tomar decisões maritais, nem familiares, principalmente quando a mulher é muito jovem, e não desempenha um trabalho bem remunerado, ou ainda, quando não trabalha.

Observam-se muitos casos em que as mulheres têm de suportar sofrer sistematicamente as imposições e humilhações dos seus maridos, sem terem a possibilidade de reclamar ou abandoná-lo porque não têm o respaldo e poder econômico.

Analisando o conteúdo trazido pelas mulheres que anunciam preocupações com o futuro, apreende-se que as mesmas estão muito mais assentadas na insegurança de manter o casamento, de encontrar um parceiro que as aceite naquela condição e no medo de vivem sozinhas.

A possibilidade de perda do parceiro sexual e a insegurança sobre a manutenção do casamento são assim expressadas:

“... a princípio ia tudo bem, depois ele foi mudando comigo... pensei que tinha carinho comigo, mas agora sinto que não lhe interesso muito como mulher. “(E7).

“sim, me sinto insegura, com medo ao pensar que meu esposo me deixe, ele é muito jovem... (E5). 
A fala das entrevistadas anuncia que o contrato que rege um casamento ou uma união que deva ser duradoura está na dependência de condições favoráveis à procriação.

"quando tocamos neste ponto, diz: dedica-te a teus filhos porque já não tem nada a oferecer.” (E2).

Da mesma forma, o medo de ficar sozinha fundamenta-se na concepção de que o poder da mulher está na procriação e perpetuação da espécie.

“... e isso me dá medo porque não mais poderei ter outro parceiro se me deixar, porque não tenho nada a oferecer." (E7)

“...mas tão pouco poderei refazer minha vida.” (E6).

A incerteza vivenciada pelas mulheres sobre o futuro que possam esperar para elas, parece-nos anunciar que para aquele grupo cultural a fertilidade e concepção são de extrema importância, revelando que a sexualidade e fertilidade caminham juntas e que a definição de gênero masculino e feminino é feita mais por critérios biológicos do que por comportamentos sociais e sexuais. 


\subsubsection{Mudanças no corpo físico e no corpo social}

O corpo humano é receptor dos acontecimentos sociais e culturais que acontecem ao seu redor, e, além disso, constitui uma unidade biologicamente cambiante que em contato com seu entorno se acha sujeito a significados diversos, importantes para a comunicação social (SALINAS,1998). Nesse sentido, as diferenças sexuais entre homem e mulher, não só obedeceriam a fatores biologicamente predeterminados, mas também à influência de fatores sociais e culturais. Se a biologia explica as singularidades de sexo, a realidade social e cultural explica a construção de uma identidade diferencial de gênero.

Ao falar sobre as mudanças ocorridas na vida das mulheres estudadas, após terem sido submetidas à histerectomia em decorrência de complicações no trabalho de parto e parto, estas enfatizam que as transformações se deram muito mais no âmbito de seus corpos sociais, gerando uma grande insatisfação em suas vidas:

"Porque depois da cirurgia me senti muito inferior sem vontade de nada, como que se o mundo se me viesse acima e me senti entrar num buraco” (E6).

"Creio que a alteração maior é que me tornei mais sensível e às vezes mais agressiva já que não voltarei ser a mesma” (E1).

“... porque me tornei muito triste, por qualquer coisa choro, me sinto só, desamparada. Não poderei me casar nunca mais,...” (E6). 
No campo das percepções de mudanças ocorridas após a histerectomia, as mulheres estudadas fazem indicações relacionadas à fragilidade com que seus corpos biológicos respondem às demandas sociais:

“agora me isolei das pessoas, porque eu não gosto de falar sobre o que me passou, sinto que vão zombar de mim, ou vão ter pena de mim...” (E1)

A separação ou abandono do parceiro após a histerectomia esteve presente na vida de algumas mulheres, e essa separação é percebida e entendida como um indicador de que seus corpos estão expostos a marcas que promovem o distanciamento social do casal.

No entanto, o distanciamento social acontece não apenas no nível marital: “...não posso me relacionar com outras pessoas porque sinto que me notam.." (E6), e esse distanciamento muitas vezes acaba sendo provocado pelas próprias mulheres:

“ sim, me isolei porque não queria que tivessem pena ou compaixão de mim pelo que passou comigo e não era casada...”(E6)

“...me tornei anti-social, não gosto de falar com meus pais, já que eles me fazem recordar o meu passado.” (E10)

Interrupções e quebras no processo de crescimento e desenvolvimento dessas mulheres, que em sua grande maioria se encontram em uma idade muito jovem, revelam o grau de infortúnio que a situação vivenciada vem causando em suas vidas. A interrupção dos estudos, trabalho, o abandono das atividades de lazer 
próprias da idade, a separação de pessoas e amigos que representam o seu grupo etário revelam o quanto ressentem por tais perdas e que pouco ou nada veio complementar tais vazios:

“...pois tampouco poderei refazer minha vida, só me resta meu filho, por ele reagi no entanto, passaram muitos meses, quase um ano para me dar conta que estava fazendo mal porque havia perdido parte de mim e agora minha correria...” (E6)

"Tudo mudou em minhas atividades e minha vida, tive que deixar de estudar, meu estado de ânimo acabou, me separei das pessoas, de minha família, pelas criticas que me fizeram como pobre, que má sorte...” (E10)

O individuo isolado, dado sua natureza relacional, não só é incapaz de realizar-se, como se atrofia no núcleo de seu ser (SANCHEZ, 2002).

O conjunto das indicações que as mulheres estudadas fazem sobre as insatisfações vividas em decorrência da perda uterina, guia-as para uma atividade de isolamento social e autopunição. Os resultados deste estudo mostram que a forma e o alinhamento das ações e condutas das mulheres estudadas constrói-se naquele contexto social a que elas estão expostas e inseridas, contexto este marcado por visões que delimitam e classificam homens e mulheres apenas por meio de seus potenciais para gerar filhos.

E como reforça Blumer (1969), qualquer linha de mudança social, desde que envolva mudança na ação humana, é necessariamente mediada pela interpretação por parte das pessoas envolvidas no processo de mudança. Complementa dizendo 
que as mudanças aparecem na forma de novas situações nas quais as pessoas têm de construir novas formas de ação.

Assim, vemos que levar as mulheres que se submeteram à histerectomia a melhorar a qualidade de suas vidas é também envolver todos os que fazem parte da rede de suas relações sociais: parceiro sexual, família, amigos e sociedade em geral. No plano individual, cuja propriedade de um corpo biológico e social que carrega a marca de uma intercorrência na reprodução da espécie, os resultados deste estudo sinalizam um conjunto de ações individuais trazidas da interpretação de cada uma das mulheres estudadas. Resta agora, à guisa de sugestão para pesquisas futuras, a análise da ação grupal ou coletiva onde se possa contribuir para com o alinhamento das ações individuais (histerectomizadas, parceiros, membros da família, amigos, profissionais de saúde entre outros) e promover mudanças para a melhoria da qualidade de vida de todos os envolvidos na convivência com mulheres que, por infelicidade deixarão de produzir filhos.

“Gostaria que uma enfermeira ou um médico viesse dizer a mim e a meu esposo que a operação não tem nada a ver com as relações sexuais...” (E1);

“...e quem poderia falar com meu esposo, para que ele entenda que o que eu passei foi para o meu bem...” (E5);

“...mas preciso de um psicólogo já que minha mãe repete sempre para falar com ele e me sentir bem” (E6);

“...sobretudo quando tocamos esse ponto, diz dedica-te a teus filos já que não tem nada a oferecer...” (E2). 
4.5 - A síntese: Metáforas da histerectomia e repercussões na qualidade de vida

Cada ser humano possui, em certo sentido, dois corpos: um corpo individual (físico e psicológico) adquirido no nascimento, e também um corpo social, necessário ao primeiro, para viver em determinada sociedade (HELMAN, 1994).

O corpo social é uma parte importante da imagem do corpo, pois fornece a cada pessoa uma base para perceber e interpretar suas próprias experiências físicas e psicológicas. É também o meio através do qual a fisiologia do individuo é influenciada e controlada pelos princípios que regem a sociedade em que vive. (HELMAN, 1994).

Os achados do presente estudo revelam que para o grupo de mulheres mexicanas aqui estudado, a sociedade tem exercido um forte controle sobre todos os aspectos de seus corpos individuais e, em especial, nos comportamentos em relação à sexualidade, às atividades reprodutivas e ao seu cotidiano.

O cotidiano dessas mulheres, analisado do ponto de vista do corpo físico, sinaliza ausência de queixas físicas, o que revela indicativos de uma normalidade, uma vez que seus corpos recuperaram-se de forma satisfatória durante o pósoperatório.

No entanto, ao analisar o olhar dessas mulheres sobre a realidade vivida por elas, deparamo-nos com um conjunto de respostas subjetivas fornecidas por elas e por aqueles que a cercam, levando-as a um mal-estar e a uma baixa qualidade de vida.

O modelo explicativo de doença que as mulheres usaram para nos revelar a forma como suas realidades estão construídas e os significados do mundo caótico 
em que passaram a viver depois do infortúnio da histerectomia, permitem-nos classificar que tal condição relaciona-se a uma metáfora.

Há muitas doenças populares arraigadas à tradição popular e quase sempre inalterada pelo modelo médico.Para Helman (1994), freqüentemente estas condições estão associadas, na imaginação das pessoas, a crenças tradicionais sobre a natureza moral da saúde, da doença e do sofrimento humano. Na mente de muitas pessoas, estas doenças são mais do que uma simples condição clínica, elas se tornam metáforas para diversos perigos da vida cotidiana.

A histerectomia na vida das mulheres estudadas representou tal condição, pois os problemas indicados por elas trazem uma série de associações simbólicas que tem afetado a maneira como elas se percebem como histerectomizadas e o comportamento de outras pessoas em relação à sua condição. Os resultados do presente estudo apontam que a histerectomia transformou-se numa metáfora na percepção do grupo estudado, ou seja, num veículo de manifestação de muitos medos e ansiedades.

Assim, no presente trabalho foi possível identificar uma série de imagens recorrentes ou metáforas da histerectomia, especialmente quando se constata uma obscuridade sobre os motivos de sua indicação e realização, quando faz a mulher sentir-se mutilada e inferiorizada, além de conviver com desajustes sociais e maritais e, ainda a colocar-se diante de um futuro incerto.

Tais metáforas têm sido utilizadas especialmente para estigmatizar este grupo de mulheres, por não ter mais capacidade de gerar filhos, considerando como se seus corpos, físico e social, existam unicamente para produzir filhos.

Percebe-se ainda, que o grande perigo destas metáforas, para o grupo estudado, reside no fato de que a visão social de punição moral como: abandono 
marital, casamentos defeituosos, isolamento social possa ser sustentada pelas instituições sociais e impeça o desenvolvimento de uma vida social e afetiva que satisfaça a elas. 


\section{Capítulo V: Considerações Finais}

O presente trabalho teve como proposta buscar uma compreensão sobre a interferência da histerectomia, realizada em decorrência de complicações no trabalho de parto e parto, na qualidade de vida de mulheres que convivem com esta situação. Para tanto, procuramos conhecer o significado da perda do útero e identificar indicadores de mudanças que interferem na qualidade de vida das mulheres depois de serem submetidas á histerectomia por problemas de parto.

Apreendemos, pelos encontros e entrevistas realizados, que as mulheres, de uma forma geral, não foram esclarecidas satisfatoriamente sobre os motivos que as levaram à mutilação. Nos seus imaginários, os motivos para tal indicação estavam relacionados a um quadro sintomatológico apresentado simplesmente pelo corpo biológico como: temperatura alta ou infecção, sangramento vaginal, anemia, distócias, risco para desenvolvimento de câncer e para salvar suas vidas.

Na perspectiva das mulheres, a perda do útero tem sido motivo de grande sofrimento o qual recai muito mais nos seus corpos sociais, uma vez que os corpos biológicos se recuperam de forma satisfatória.

A perda como motivo de sofrimento, segundo o grupo estudado, fundamentase na experiência de ter um corpo vazio, mutilado, fazendo as mulheres sentirem-se inferiorizadas, convivendo com desajustes sociais e conjugais, além de considerarem incerto seus futuros. 
A lógica para seus sofrimentos assenta-se na observação de não obediência aos padrões sociais e culturais dirigidos às expectativas de papeis para os gêneros masculino e feminino na sociedade, revelada especialmente na capacidade da mulher para procriar. A inadequação deste atributo; que para elas parece caracterizar os motivos de uma convivência não harmoniosa entre sexualidade, status conjugal e constituição da família; mostrou-se como destaque nas suas subjetividades, a ponto de classificar seus corpos sociais como doentes e por isso sofrem.

Estes achados possibilitaram-nos ainda, formular o pressuposto de que as mulheres que realizam histerectomia em decorrência de complicações do parto apresentam insatisfações quanto à qualidade de suas vidas, especialmente naquelas dimensões que se dirigem para a sexualidade, constituição da família e convívio social.

Ao concluirmos o presente trabalho identificamos que foi de grande importância o conhecimento das questões subjetivas e socioculturais que permeiam o universo simbólico das mulheres, pois isso possibilitou a identificação de metáforas da histerectomia que interferem sobremaneira na qualidade de suas vidas, seja estigmatizando-as por não mais produzirem filhos ou punindo-as moralmente, através do abandono marital, dissolução do casamento e isolamento social, o que as impede de levar uma vida social e afetiva que as satisfaça. 


\section{CAPÍTULO VI: Referências Bibliográficas}

ACOSTA, V.G. Vía Crucis de la Muerte Materna: Oficina regional de UNICEF para América Latina y el Caribe; 2000 Documento de Trabajo

ALDRETE, R. J. Filosofía de la Educación y Genero: Seminario Interdisciplinario, Facultad de Filosofía y Letras. UNAM México 1997. 11-24 p.

AROSTEGUI, I. Evaluación de la calidad de vida: en personas adultas con retraso mental en la comunidad autónoma del País Vasco. Universidad de Deusto. España. 1998.

ARREDONDO, C. J. El poder y dominación en el Matrimonio Romántico: Seminario interdisciplinario, Facultad de Filosofía y Letras. UNAM. México 1997.p

BARDIN, L. L'analyse de contenu:. PUF. Paris. 4a ed. 1979.233 p.

BANCO MUNDIAL. Invertir en salud: Washington, D.C.; 1993 Informe sobre el Desarrollo Mundial

BAKSHI, S.; MEYER, B. Indications for and outcomes of emergency: peripartum Hysterectomy. A five-year review. J Reprod Med, n. 9. 733-735 p. Jul/ago. 2000.

BARKER, M. G. Psychiatric Illness after hysterectomy: British. Med .J. v. 2, New York 1968.91-95. p

BARBIERI, T. Sobre la categoría de género: Una Introducción Teórico-metodológica, Revista Interamericana de Sociología, México: año VI, no. 2, 23-32 p. 1992 
BARCLAY, L. M. Pruebas (Juicio) Aleatorias en Metrorragias: Comparan Terapia Médica with Hysterectomy, Washinton 2004

BERNHARD, L. A. Black women's concerns about sociality and hysterectomy: Sage, v. 2 n.2, 1986. 25-27p.

BORTHWICK, S. A.. Quality of life and quality of care in mental retardation: In L. Rowitz (Ed.), Mental retardation in the year 2000 66. Berlin: Springer-Verlag 2002 $52-60 \mathrm{p}$.

BROADHEAD, W. The epidemiologic evidence for a relationship between social support and health: American Journal of Epidemiology, Baltimore, v. 117, n. 5, 525-537p.1983

BLUMER, H. Symbolic Interaction: - Perspectives and Methods. New Jersey, Prentice Hall, 1969. 207 p.

BOURDIEU, P. O Poder simbólico: Rio de Janeiro: Tradução Fernando Tomaz $6^{a}$. ed. Rio de Janeiro. Rio de Janeiro: Bertand, 2003. 322 p.

CAMPBELL, A. Subjective Measures of Well-Being: American Psychologist. v. 31, Washington.117-124 p. Feb. 1990

CAMPBELL, J. C.; BUNTING, S. - Voices and paradigms: perspectives on critical and feminist: theory in nursing. Adv. Nurs. Sci. v.13 n.3, 1-15 p. 1991

CALIRI, M. H. L. Tentando resolver as Incertezas: Trajetória das mulheres ao Enfrentarem o Progresso da Histerectomia Ribeirão Preto,1994.143 f Tese Dissertaçao (Doutoramento) Escola de Enfermagem de Ribeirão Preto Universidade de São Paulo,1994.

CAMPOS, O. C. Cien Años de Mortalidad en México: en Revista Demos, El Colegio de México; 34-46 p. 2000.

CELLA, D.; TULSKY, D. Measuring quality of life today: methodological aspects. Oncology Washington; n.5 v. 4. 29-38 p. 1997

CEPAL, La brecha de la equidad: América Latina, el Caribe y la cumbre social. Santiago de Chile: 1997. 
CIPD, Conferência linternacinal Sobre População E Desenvolvimento: O Cairo, Egipto 1994

CHARON, J. M. Symbolic Interactionismo: 3ra. Ed. New Jersey Prentice Hall, 1989. 204 p.

CHORAYEB, N. Saùde è qualidade de vida: Modismos e llusões. O Estado de São Paulo: 1996. 23. p.

DENNERSTEIN, L.;VAN HALL, E. Psychosomatics Gynecology: New York, Parthenon, 1986. Cáp. 8,: Hysterectomy, 119-127p.

DENNIS, R.; WILLIAMS, W. Calidad de vida como contexto: para la planificación y evaluación de servicios para personas con discapacidad. Siglo Ceroo, 1994 p. 25, 155

DILDY, G.S.; SAFFER, C.S. Pelvic pressure pack for catastrophic postpartum hemorrhage. Obstetric Gynecology, p. 95 n.1 April 2000

DICKEY, B.; HENDRICK, W. Evaluating health status: In: Sederer LI, Dickey B. Outcomes assessment in clinical practice, New York Williams and Wilkins, 1996: p. $45-54$.

DIXON, M. R. Abortion policy and women's: health in developing countries. Int. health serv. New York: 297-314 p. n. 20 Feb. 1995.

DOS SANTOS, I.: FIGUEIREDO, A.N. et al. Enfermeira Fundamental: Realidade, Questões, Soluções: São Paulo: Editora Atheneu, 2001 vol. 1. 280 p.

DRUMMOND, J.; FIELD, P.A. Emotional and sexual sequelae following hysterectomy. Health Care for Women International. New York, n.3 v.5, p.261. 1984

FEATHER, B.; WAINTOCK, J. Perceptions of posmastectomy patients: Part I: the relationships between social support and network providers. Cancer Nursing, New York, v. 12, n. 5, 1989. p. 293-300 
FERRANS, C.P. Quality of life Through The Eyes of survivors of Breast Cancer. Oncoll, Nursing. Forum, v.17, n.10, 1994. p. 116-45-51

FERREIRA, MA. O corpo no cliente cuidado de enfermagem: representações de clientes hospitalizados, Rio de Janeiro: EEAN /UERJ, Tese (Doutorado em Emfermagem. Rio de Janeiro, 1999 p. 267

FREEMAN, R. M. Gynecology of Woman: Professor of Medicine and Obstetrics and Gynecology Albert Einstein College of Medicine Bronx, NY 1993. 367 p.

FIELD, P. A.; MORSE, J. B.; SLESINSKI, M. J. Nursing Research: The applications of qualitative approaches. USA, Aspen, 1985.

FELCE, D.; PERRY, J. Quality of life: It's Definition and Measurement: Research in Developmental Disabilities, 1995. v.16, n.1, p. 51-74.

FOUCAULT, M. Historia de la Sexualidad: o uso dos prazeres. 7 ed. Tradução de Maria Thereza da C. Albuquerque. Rio de Janeiro: Graal, 1994.

FORATINI, O.P. Qualidade de vida e meio urbano. A cidade de São Paulo, Brasil. Rev. Saùde Pùblica, USP, n. 25, v.2, p. 75-86. 1991

GARCIA, T. M; SOBRADO, R. Z. Impacto de la panhisterectomía em la calidad de vida de la mujer: Rev. Cubana Medicina General Integral La habana Cuba v.16 n. 5 , p. 12 sep/oct. 2000

GARCIA, I. J.; MOLINA, V. R. Directores Del Departamento de Obstetrícia e Ginecologia. Universidade do Zulia Hospital Dr. Manuel Noriega Trigo IVSS. Maracaibo Venezuela, inestigação publicada em ano 2000.

GATH, D.; COOPER, P.; DAY, A.Hysterectomy and psychiatric disorder: I. Levels of psychiatric morbidity before and after hysterectomy. British J. Psych. v. 140 p. 335-350, 1992.

GEERTZ, C. A Interpretação das culturas. Rio de Janeiro Guanabacara Koogan, 1989. 
GÓMEZ, D. H.; GARNICA, S. J.; VALDESPINO, G. J. L. Patrones de lactancia y ablactación en México Encuesta Nacional de Salud 1998. Salud Pública Mex 1998; n. 31: 725-734.

GHORAYEB, N. Saùde è qualidade de vida: Modismos e llusões. O Estado de São Paulo,1996 $3^{a}$ feira, 25/07/89. p. 23.

GOULD, D.; WILSON, J. A comparison of recovery following hysterectomy and major cardiac surgery. J adv. Nursing, v. 10 New York 1985. p. 315

GONZALEZ, N. M. Symposium de calidad de vida: generalidades, mediciones utilizadas en medicina, elementos que la componen. Arch. Reumatol 1993; v.4 n.1: p. $40-42$

GUTIERREZ, M. G. R. Intervençao do Enfermeiro: uma analise a partir da pratica: São Paulo, tese (Doutoramento) escola de enfermagem da Universidade de São Paulo. 1989, p. 101

HAGUETTE, T.M.F. Metodologias Qualitativas na Sociologia. 9a. ed Rio de Janeiro Brasil Vozes, 2003. 224 p.

HALLERT, C.; LOHINIEMI, S. Quality of life of celiac patients: living on a glutenfree diet. Nutrition. 1999; v.15 (10): p. 795

HELMAN, G. Cultura Saúde e Doença: 2da. Edição,Tradução Eliane Mussinich. Porto Alegre Editorial Artes Medicas, 1994 titulo original: cultura Health and Illness. $320 \mathrm{p}$.

HENSE, D.S.S. Tendo que operar-se A experiência do paciente cirúrgico e sua espiritualidade. Florianópolis, Dissertação (mestrado), Universidade Federal de Santa Catarina. 1987, p. 399

HIERRO, G. Naturaleza y fines de la educación superior: Facultad de Filosofía y Letras. México. UNAM Coordinación de Humanidades 3ra. Ed. México 1996, p.302

KRIPPENDORF, K. Metodología de análisis de contenido:. Teoría y práctica, Barcelona, Piados, 1990. 240 p. 
KOOPMAN, H. M.; KOLSTEREN, M.M. P. Health-related quality of life of children with coeliac disease: In: Lohinimei $S$, Collin $P$, Mari $M$, eds. Changing features of coeliac disease. Tampered: The Finnish Coeliac Society, 1998 p. 117

KRUEGER, J. C.; HASSEL, J.; GOGGINS, D. B.; ISHIMATSU, T. Relationship between nurse counseling and sexual adjustment after hysterectomy. Nurse. Res. v. 28 n. 3, 1979 p. $145-150$.

LAMAS, M. La antropología feminista y la categoría de género: Nueva antropología, v. VIII, n. 30, México, 1996. p. 54-58

La antropología feminista y la categoría de género, en El género: la construcción de la diferencia sexual compilación. Coord. UNAM. Coordinación de Humanidades México 1996.

LANGER, G. A.; ROMERO, M. Diagnóstico en Salud Reproductiva en México, Reflexiones, Sexualidad, Salud y Reproducción Revista El colegio de Sociología de México. v. 4 n. 51996 p. 38-42

LANGER, G. A. Maternidad desigual en México, marginalización de estados. Revista El colegio de Sociología de México. v. 7 n. 101995 p. 24-30

La mortalidad materna en México: "La contribución de aborto inducido"; Revista El colegio de Sociología de México. v. 3 n. 3 2000. p. 12-25

LESLIE, S.; GUPTA, G.R. Utilization of formal services for maternal nutrition and health care in the Third World: Washington, D.C: International Center for Research on Women, 1992.

LEVINE, M.N.; GUYATT, G.H, et al. Quality of life in stage II breast cancer: an instrument for clinical trials. J Clin Oncol n. 6 p.12: 1988

LOHINIEMI, S.; MUSTALAHTI K, C. P. Measuring quality of life in coeliac disease patients: In: Lohiniemi S, Collin $P$, Mäki $M$, et d s. Changing features of coeliac disease. Tampere: The Finnish Coeliac Society, 1998: 71. p.

MARCON, S. S. Vivenciado a gravidez. Florianópolis,. Dissertação (Mestrado) Universidade Federal de Santa Catarina. 1989, p. 383 
MARTINEZ, C. F. Ciencia y Humanismo al servicio del Enfermo: edi. El Manual Moderno. UNAM. Facultad de Medicina. p. 88 México, 2003

MAYER, R.; QUELLET, F. Méthodologie de recherche pour les interventants sociaux : Boucherville. Gäetan Morin Editeur. Montreal-Paris-Casablanca. 1991 p. 473-502

MÉXICO Encuesta Nacional de Salud SSA México, 2000.

MÉXICO, Censo de Población y vivienda Instituto Nacional de Estadística Geografía e Informática México, 2000.

MÉXICO Diagnostico de Salud de Ciudad Nezahualcoyotl: Secretaria de Salud del Estado de México. 2000

MÉXICO, Norma Técnica Oficial Mexicana .NTM 9: Para la atención de la mujer durante el embarazo, parto puerperio y del recién nacido. Distrito Federal 6 de enero de 1995.

MÉXICO, Programa de Salud Reproductiva y Sociedad: año I No. 3, Mayo de 1995

MÉXICO, Censos Hospitalario Secretaria de Salud: Estadísticas de morbimortalidad materna. México, 2000.

MÉXICO Sistema Nacional de Salud (SNS); Programa Nacional de salud, 20012006 en Programa Nacional de Desarrollo, México, 2001-2006

MÉXICO Sistema Nacional de Salud (SNS); Informe de Salud México 2001

MÉXICO Sistema Nacional de Salud (SSA), Programa de Acción: Arranque Parejo en la Vida: Defunciones en hospitales públicos según población; ED. SSA, 2001

MÉXICO Sistema Nacional de Salud, SSA Programa Nacional de Salud, 20012006. 
MELODY,G.F. Depressive reactions following hysterectomy. Am. J. Obstetrict. Gynecol. v. 83 1962. 410-413 p.

MINAYO, M.C. de S. O desafio do Conhecimento: Pesquisa Qualitativa em Saùde. 7.a Edição, São Paulo/Rio de Janeiro. Hucitec/Abrasco, 2000. 269 p.

MONDRAGON, C. H. Obstetricia Básica e Ilustrada: ed. 3ra edición Trillas, México $2000320 p$

ORGANIZACIÓN MUNDIAL DE LA SALUD. Mortalidad materna: ayudar a las mujeres a evitar el camino de la muerte. Crónica OMS 1996, v. 40: p.195-205

Estimaciones de Mortalidad Materna: Un Nuevo Acercamiento entre la OMS y UNICEF, en Informe sobre Salud en el Mundo 2002

ORGANIZACIÓN PANAMERICANA DE LA SALUD. Plan de Acción Regional para la Reducción de la Mortalidad Materna en las Américas. Washington DC: OPS, 1990. (Documento CSP23/10).

OPS La salud de la mujer en las Américas: Washington, D C, 1995. (Publicación científica 488). Núm. 6

Maternidad Saludable 1998; en Revista Panamericana de Salud, Vol. 12,

Maternidad Saludable 2000 en Revista Panamericana de la salud, vol. 20 Nùm. 10

Evaluation of the Regional Plan of Action for the Reduction of Maternal Morbidity. Washington DC: PAHO; 1996.

POLIT, D. F.; HUNGLER B. P. Investigación científica en ciencias de la Salud: Sexta ED, edi. McGraw Hill Interamericana México D. F. 2003 p.310

PROFAMILIA, INTERNATIONAL, M. Encuesta Demográfica y Salud de Colombia: Santa Fe de Bogotá; 1996. 
QUIROZ, M.I.P. de Variações sobre a técnica de gravador no registro de informações viva. Sao Paulo: Editor T.A. Quiroz , 1987.

RENDÓN L. A Conceptual framework and suggested interventions for maternal mortality in Latin America. (Documento mimeografado). México, DF, 1991

REIS, M.M. A Enfermagem e a imagem corporal de pacientes histerectomizadas. Salvador, Disseração. (Mestrado) Universidad Federal da Bahia. 1987. p. 93

RICHARDSON, R.J. Pesquisa Social: Métodos e Técnicas 3ra. edición Ed. Atlas, São Paulo:1999 p. 334

ROBLES, S.; WHITE, F.; PERUGA, A. Trends in Cervical Cancer Mortality in the Americas. FHI-AIDSCAP, PAHOWHO. The Status and Trends of the HIVAIDS Pandemic South America. XI International Conference on AIDS. Vancouver, Canadá. July 1996.

RODRIGUES, J. C. Tabú do Corpo. 3ra. ed. achiamé Rio de Janeiro1984 . p.173

RODRÍGUEZ, D. C. Doctora en Sociología. Coordinadora de la Maestría en Ciencias de la Comunicación de la Facultad de Ciencias Políticas y Sociales de la UNAM México, 1997

ROMO, G. C. Maestro en Población; Doctorante en Ciencias por el CEDEM de la Universidad de La Habana Cuba; Docente-Investigador del Programa de Maestría en Población y Desarrollo de la Unidad Académica de Ciencias Sociales, Universidad Autónoma de Zacatecas, México 2002

RUFINO,N. A. Qualidade de Vida: compromisso histórico da epidemiologia. Saúde em Debate, Brasil n. 35, 1992, 63-67.p.

SANCHEZ, V. A. La Sociedad y la Familia: 5ª edición Esfinge, México, 2002.

SALINAS, S. Identidad, Poder y Sexualidad en adolescentes: de zonas periurbanas de La Paz y El Alto. Educación en Población, UNESCO, MECD, UNFPA. La Paz. 1998. 
SCHALOCK, R.L. The quality of children's lives. In A.H. Fine y N.M. Fine (Eds.), Therapeutic recreation for exceptional children. Let me in, I want to play. Second edition. Illinois: Charles C. Thomas. 1996

SCHALOCK, R.. L. Quality of Life. Aplication to Persons with Disabilities. Vol. II. M. Snell, \& L. Vogtle Facilitating Relationships of Children with Mental Retardation in Schools Illinois v. II. 1996 p. 43-61

SCHALOCK, R.L. Three decades of Quality of Life: Informe manuscrito, Illinois. Chicago 1997

SCOTT, J. W. El género: una categoría útil para el análisis histórico, Historia y género: las mujeres en la Europa moderna y contemporánea. 1992

SHEEMAN, E. Cómo mejorar tu autoestima: Madrid :Ed. Océano España 2000. p. 160.

SPIZER, D. A.J.; HALL,J. et al. Measuring the quality of life of cancer patients: A concise QL-Index for use by physicians. J Chiron Dis; n 34 v. 121981 p. 585-97

STRAUSS, A.L.; CORBIN, J. Basics of qualitative research grounded Theory: procedures and techniques. New York Sage. 1990

TRIVINOS, A.N.S. Introdução à Pesquisa em Ciências Sociais: A Pesquisa Qualitativa em Educação. São Paulo, Atlas, 1990. p.175

UNICEF MATERNIDAD SEGURA, Fundación Internacional; Incidencia de la Moralidad Materna en los Países Pobres 2000.

UNGO, M. U. Del feminismo al enfoque de género: en FEM, año 17, no. 124, junio 1999, p. 7-12.

Verdugo, M. A.; CABAllo. C.; PELÁEZ, A.; PRIETO, G. Calidad de vida en Personas Ciegas y con Deficiencia Visual: Unpublished manuscript, Universidad de Salamanca/Organización Nacional de Ciegos de España. 2000.

WILLIANS A Obstetricia: 17 edición, Editorial Salvat México.2000. 546 p. 
WILLIANS, M. A. Easier Convascence: Am. J. Nursing v. 76 n. 3 1979. 438-40 p.

WILSON, H. S. Research in Nursing: a Addison- Wesley, Strategies of Field Research: first hand knowing under natural conditions; California, 365- p 393 1985,cap. 13

WONG, W.C.; KUN K.Y.; TAI C.M. Emergency obstetric hysterectomies for postpartum hemorrhage. J Obstetric Gynaecology Res Chicago, p. 425-430 n 6 Dec. 25.1999.

YAEGASHI, N.; CHIBA, S. A.; OKAMURA, K. Emergency postpartum hysterectomy in women with placenta previa and prior cesarean section. Int J Gynecology Obstetric Chicago, p. 49-52 n 68 v 1.Jan 2000 
ANEXO A 


\section{APÊNDICE A \\ Termo de Consentimento Livre e Esclarecido}

Nome da Pesquisa:Histerectomia decorrente de complicações do parto em um grupo de mulheres mexicanas: uma visão sociocultural.

\section{Pesquisador Responsável: María Teresa Cuamatzi Peña}

Informações: Nesta investigação queremos estudar se a histerectomia realizada em mulheres jovens, como conseqüência de complicações durante o trabalho de parto e parto, afeta sua vida, fisica, sexual, psicológica, social e familiar ou conjugal e também saber se esta situação interfere em sua qualidade de vida.

Com a investigação esperamos compreender melhor qual é o processo ou experiência vivida por você com esta nova situação.

Estou convidando você para participar desse estudo e assumo o compromisso de manter sigilo quanto à sua identidade, como também garanto que o desenvolvimento da pesquisa não tem riscos para sua saúde, nem para sua familia.

Em caso de seu consentimento, você terá liberdade de retirá-lo a qualquer momento, embora a entrevista já tenha sido realizada, já que não é uma obrigação para você.

\section{Pesquisador Responsável}

$\mathrm{Eu}$ No. Exp. .__ assinando abaixo recebi a informação antes mencionada, e conciente de meus direitos, estou de acordo em participar. no presente estudo

1. A garantia de receber em qualquer momento respostas ou esclaracimento, a qualquer dúvida respeito à entrevista, riscos, benefícios e outros relacionados ao estudo me será respondida.

2. A liberdade de retirar meu consentimento, em qualquer momento, e deixar de participar do estudo, sem que isso traga conseqüências ao mesmo, ou a minha pessoa.

3. A asegurança de que não serei identificada e que será mantida a informação com caráter confidencial

4. A segurança de que serei inteirada dos resultados do estudo e os benefícios que podem trazer para melhorar a informação que devemos receber quando passamos por este processo. Tenho conhecimento do exposto anteriormente e desejo participar do estudo e declaro que não me oponho a que seja gravada minha entrevista.

Cd. Nezahualcoyotl, México a de. 


\section{APÊNDICE B}

\section{ENTREVISTA}

1.Nome

2.-Idade 3.-Religião 4.-Estado civil

5.-Partos 6.-Cesáreas 7.-Abortos 8.-Numero de filhos

9-Data do ultimo parto

10.Escolaridade

11. Trabalha atualmente $\operatorname{Sim}($ ) Não( ) Endereço

12.-Tipo do Trabalho Renda Mensual

13.-Você poderla me contar como foi para você o fato do que lhe aquietassem o útero ou matriz que é parte de seu corpo?

$\overline{14-O}$ que significa ou significou este fato para você em sua vida pessoal e familiar?

15.-Como você se percebe agora depois dessa cirurgia?

16.-Mudou alguma coisa em sua vida depois da cirurgia?

17.-Sente que a cirurgia trouxe alguma alteração em seu modo de vida, em seu modo de se relacionar com as pessoas, com alguém em particular, com você mesma?

18.-Sua relação com seu companheiro continua igual ou mudou?

19.-Você mudou o seu modo de ser?

20.-Teria algo mais que acrescentar, ou que gostaria de falar ou perguntar? 